\title{
Systematics of pterobranchs from the Cambrian Period Burgess Shales of Canada and the early evolution of graptolites
}

\author{
Greta M. Ramírez-Guerrero \& Christopher B. Cameron
}

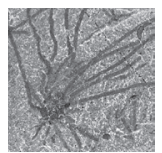

\begin{abstract}
Pterobranchs originated in the basal Cambrian (Fortunian) and are mostly known by their tubes preserved in the fossil record. The earliest forms are represented by bushy erect growing colonies that are not widely studied due to their scarcity, preservation quality and species misidentification. For this reason, early phylogenetic relationships within the group are not clearly established. Middle Cambrian Burgess Shale graptolites were poorly known, based on the presence of Chaunograptus scandens, some debatable species of the genus Yuknessia, and other undetermined fragmented material. This study represents a complete description of $C$. scandens, a consensus for Yuknessia simplex and Y. stephenensis, and new reports of Protohalecium hallianum and Mastigograptus sp. from the Burgess Shale localities, which have also been found in other Burgess Shale type localities in Utah and Australia. Phylogenetic analyses of 34 discrete morphological traits from these Burgess Shale genera and some known benthic and planktic taxa $(n=22)$, place these Cambrian species as basal forms closer to the pseudocolonial pterobranch Cephalodiscus and the living graptolite Rhabdopleura. $•$ Key words: graptolites, Hemichordata, middle Cambrian, Burgess Shale.
\end{abstract}

Ramírez-Guerrero, G.M. \& Cameron, C.B. 2021. Systematics of pterobranchs from the Cambrian Period Burgess Shales of Canada and the early evolution of graptolites. Bulletin of Geosciences 96(1), 1-18 (7 figures, 2 tables). Czech Geological Survey, Prague. ISSN 1214-1119. Manuscript received May 3, 2020; accepted in revised form August 25, 2020; published online November 16, 2020; issued January 10, 2021.

Greta M. Ramírez-Guerrero \& Christopher B. Cameron, Université de Montréal, Département de sciences biologiques, C.P. 6128, Succ. Centre-ville, Montréal, QC,H3C 3J7, Canada; greta.ramirez@umontreal.ca

Graptolithina is a subclass of cosmopolitan marine colonial pterobranch hemichordates mostly known by their tubes, preserved in the fossil record since the Cambrian Period. Graptolites differ from their sister group Cephalodiscida, by the presence of a stolon system that supports a colonial lifestyle, the presence of a larval prosicula, and the anatomy of the zooids. Although zooids with preserved morphological details are essentially unknown among fossil graptolites, zooid anatomy is well known from the extant species Rhabdopleura (Mitchell et al. 2013, Maletz \& Beli 2018). The subclass comprises the orders Dendroidea, which includes the benthic organisms with an encrusting to erect, bushy morphology formed by irregular branching, as well as the derived, planktic Graptoloidea (Maletz 2014b, Maletz \& Cameron 2016).

Due to poor fossil preservation, taphonomic processes, and similarities in morphology between taxonomic groups, identification of the specimens is difficult and sometimes mistakenly done, especially in Cambrian forms. The useful criteria to define a graptolite, when the soft-tissue material is not available, include an organic tubarium with fusellar structures surrounded by secondary cortical tissue, and the stolon system (Mitchell et al. 2013).
Even when these characteristics are preserved, scanning electron microscopy is frequently used to obtain the most details from the specimens; otherwise, mostly outlines of organic-walled fossils are available for determination (Maletz et al. 2005, LoDuca et al. 2015a).

An example of misidentified pterobranchs is the genus Yuknessia, which was originally regarded as an alga (Walcott 1919), but is now recognized as one of the earliest known pterobranchs from the Cambrian Series 3, based on the SEM identification of fuselli in two species (Steiner \& Maletz 2012, LoDuca et al. 2015a). Like Yuknessia, a closer look at other taxa may establish a pterobranch affinity (e.g., Dalyia racemata and Malongitubus; Maletz \& Steiner 2015, Hu et al. 2018. See Maletz \& Beli 2018 for further discussion). We refer to these early forms simply as pterobranchs, based on their organic tubes with fusellar structures, because it is nearly impossible to classify them as cephalodiscids or graptolites.

The pterobranch fossil record from the early and middle Cambrian is less complete compared to the Ordovician and Silurian periods (Rickards \& Durman 2006), making difficult our understanding of the origin and early evolution of graptolites. It is known that early graptolites 
represent benthic forms that originated in the Cambrian, some incertae sedis taxa persisted into the Recent, and the order Dendroidea until the Carboniferous. Less long is the existence of the planktic Graptoloidea, which lived from the Early Ordovician until the Early Devonian (Rickards \& Durman 2006, Maletz 2014a).

Maletz (2019a) recognized the oldest pterobranch record from the early Cambrian (Terreneuvian, possibly Fortunian) from fragments identified as Sokoloviina costata from the Rovno Horizon, Ukraine (Kirjanov 1968). $S$. costata was also identified in the transition between the Fortunian and Stage 2, from the Lontova Formation in Estonia (Slater et al. 2018a). Other small pterobranch fragments have been found in a Burgess Shale-type deposit in North Greenland (Series 2, Stage 3) (Slater et al. 2018b). True colonial pterobranchs (Graptolithina) are known from the early middle Cambrian (Series 2, Stage 4) such as Sphenoecium wheelerensis (Maletz \& Steiner 2015) (Fig. 1). Graptolites then radiated and exhibited a large disparity before the Late Ordovician extinction (Bapst et al. 2012), and until recently were thought to have gone extinct during the Carboniferous. Mitchell et al. (2013) placed the living benthic Rhabdopleura within the Graptolithina, however, based on similarities of the tubarium construction and structure. Rhabdopleurids then, are living benthic graptolites that have survived from the Cambrian to the present (Mitchell et al. 2013).

Acorn worms (Cameron et al. 2000, Simakov et al. 2015) and pterobranchs (Romer 1967, Jefferies 1986) are generally regarded as key groups to understand the origin of the deuterostome phyla. Rickards \& Durman (2006) and Maletz \& Steiner (2015) described some Cambrian graptolites and provided a possible scenario of their early evolutionary relationships, but neither made detailed reference to Burgess Shale forms. Herein we provide a taxonomic classification of the pterobranchs from Burgess Shales of British Columbia, Canada within the context of other early Paleozoic pterobranch species. We then use these taxa and characters to revise the phylogenetic character matrix of Mitchell et al. (2013), to resolve the origins and early evolution of Pterobranchia.

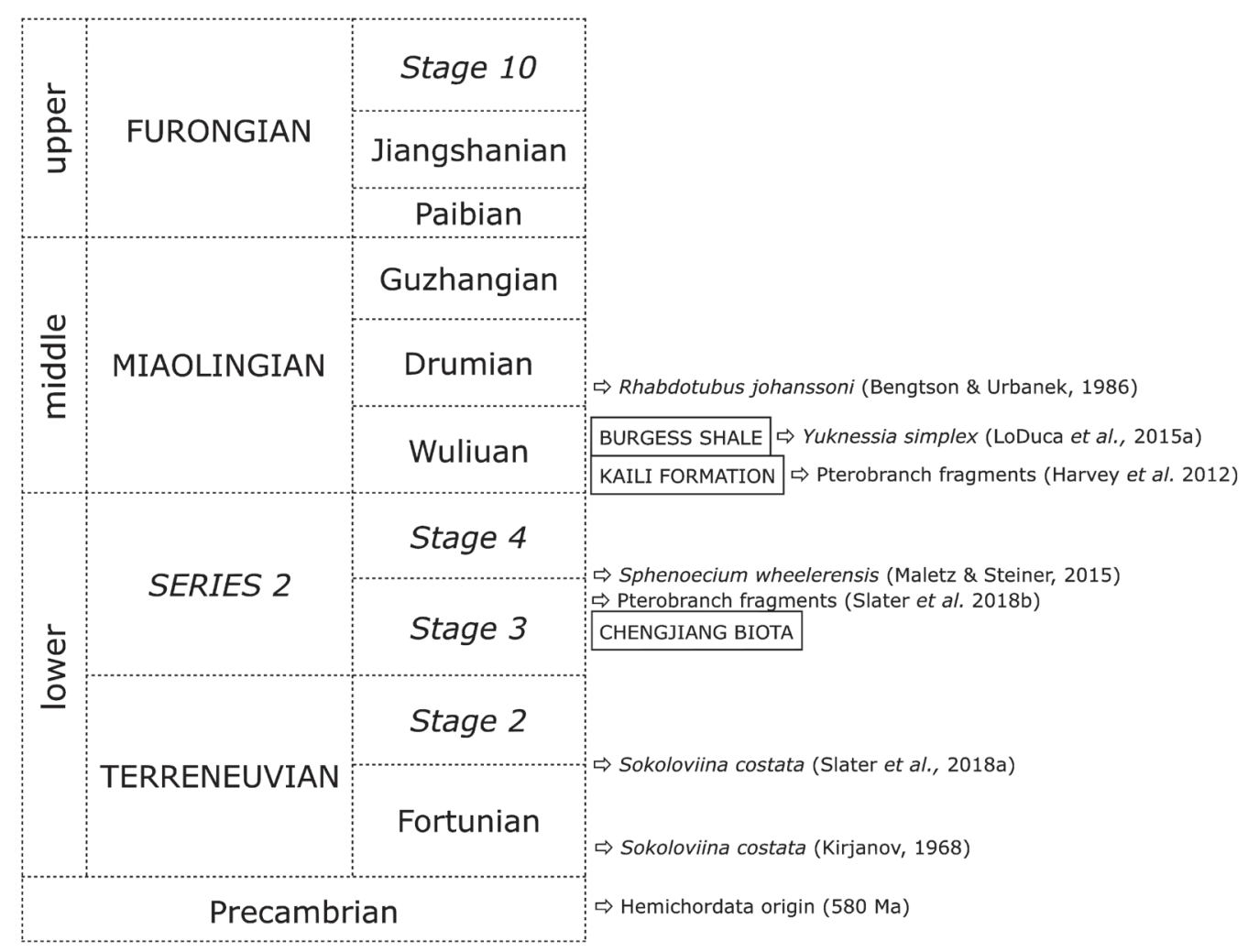

Figure 1. Earliest Cambrian pterobranch records, based on organisms that show some features that recognize them as authentic pterobranchs. Molecular clocks estimate the origin of hemichordates in the Ediacaran $(580 \mathrm{Ma})$. Oldest record is Sokoloviina costata from the Rovno Horizon, Ukraine (basal Cambrian) and some possible fragments identified as the same species from the Lontova Formation, Estonia from the transition between Fortunian-Stage 2. Galeaplumosus abilus was identified as a possible pterobranch zooid from the Chengjiang Biota (Hou et al. 2011), however, a cnidarian affinity has more support. Small carbonaceous fragments of pterobranchs were collected from the Buen Formation, Sirius Passet, Greenland from the Stage 3. Later records consist of more complete species found in different localities. Sphenoecium wheelerensis is considered the oldest record of a true colonial graptolite and Rhabdotubus johanssoni as the oldest recognized rhabdopleurid. 


\section{Methods}

All the specimens were collected in the middle Cambrian localities of Walcott Quarry, Miller Pass, Haiduk Peak, and Trilobite Beds, in Southeastern British Columbia, and curated at the Royal Ontario Museum and the Royal Tyrrell Museum. Since the specimens are flat and reflective, they were photographed using direct and cross-polarized light, under dry and wet conditions to capture different details; high resolution photographs were obtained using a Leica M125C stereoscopic microscope.

Backscatter scanning electron microscopy was used as a non-destructive technique to reveal ultrastructural characteristics of thin-walled fossils with organic remains, such as the presence of preserved diagnostic fusellar or stolon structures. The fossils analyzed were preserved on sediment surfaces and no isolation attempts were made. Specimens were glued on sample holders and covered with carbon tape to reduce electron charging. All the samples were examined uncoated under low and high vacuum conditions with accelerating voltages of $5-15 \mathrm{kV}$, at different working distances depending on the thickness of the slabs, on a JEOL JSM-6610LV, in the Department of Earth Sciences, University of Toronto. Measurements of the specimens were made through digitally processed images.

\section{Phylogenetic analysis}

A phylogenetic analysis was performed using 22 taxa and 34 discrete morphological traits. The taxa included most of the pterobranch genera examined in Mitchell et al. (2013), plus the taxa reported here from the Burgess Shale (Yuknessia, Chaunograptus, and Protohalecium). The two species of tubicolous Cambrian acorn worms (Spartobranchus tenuis and Oesia disjuncta) were used as outgroups. The morphological character traits used were those of Mitchell et al. (2013), with some modifications based on recent literature (Tab. 1), and character states for the acorn worm outgroups including aspects of their tubes. These changes are indicated in bold in the character matrix (Tab. 2).

Chaunograptus is very likely a graptolite yet this has not been confidently demonstrated because we did not identify fuselli. It was included in the analysis because the thecal organization is similar to other benthic forms (acute conical alternated thecae). Cephalodiscus Orthoecus/ Idiothecia and Cephalodiscus Cephalodiscus/Acoelothecia were included as in-groups, rather than treated as paraphyletic outgroups as per Mitchell et al. (2013), due to the inclusion of the basal tubicolous enteropneusts as the new outgroup.

The main challenge when trying to find diagnostic characters in pterobranch fossils is the poor preservation
Table 1. Updated list of literature consulted for the character matrix coding and discussion additional to the sources cited by Mitchell et al. (2013).

\begin{tabular}{ll}
\hline Genus & Reference \\
\hline Chaunograptus & $\begin{array}{l}\text { Ruedemann (1931), Ruedemann (1947), Urbanek } \\
(2018)\end{array}$ \\
& Walcott (1919), LoDuca et al. (2015a, b), Maletz \& \\
Yuknessia & Steiner (2015) \\
Spartobranchus & Caron et al. (2013) \\
Oesia & Nanglu et al. (2016) \\
Epigraptus & Bengston \& Urbanek (1986), Mitchell et al. (2013) \\
Protohalecium & Quilty (1971), Rickards \& Durman (2006) \\
Callograptus & Ruedemann (1931) \\
Dendrotubus & Maletz et al. (2016) \\
Kozlowskitubus & Mierzejewski (1988) \\
Dictyonema & Maletz (2019b) \\
Bulmanicrusta & Maletz (2014b) \\
Bithecocamara & Maletz (2014b) \\
Cephalodiscus & Maletz \& Gonzalez (2017) \\
Rhabdopleura & Kozlowski (1966) \\
\hline & \\
\hline
\end{tabular}

of the tubes and the almost total absence of zooids. In most cases, only outlines or dim imprints of the organic tube remain for identification. Poor preservation hampers the identification of small differences in tube structure. In these cases, we sometimes found additional characters states using computed tomography or scanning electron microscopy.

A list of phylogenetically informative external characters and character states including absence/presence or multistate attributes is provided below. The character descriptions were taken from Kozlowski (1949), Bulman (1970), Urbanek \& Mierzejewski (1984), Rickards \& Durman (2006), Mitchell et al. (2013), Maletz et al. (2014), Maletz et al. (2016) and focus on structures usually observed in dendroid-like graptolites, meaning that the planktic forms may not accurately fit into this terminology.

1) Prosicula: Proximal conical part of the sicula (initial zooid constructed tube) where the larva undergoes metamorphosis [0 - absent; 1 - vesicular (rounded or truncated); 2 - tubular; 3 - caudal/pointed];

2) Helical line: Spiral outline around the prosicula (do not confuse with regular fuselli) $(0$ - absent; 1 - present);

3) Metasicular opening in prosicula: Refers to the pore left by the emergence of the first zooid in the early development of the tube; it is observed between the prosicula and metasicula. If the change is gradual and smooth is considered as 'primary', whereas 'resorption' is observed as an abrupt angular transition formed 
Table 2. A - data matrix including 22 pterobranch and enteropneust species of 34 morphological characters used to establish the group relationships. Bold face states are modified from the morphological matrix of Mitchell et al. (2013), plus two additional characters, the new Burgess Shale graptolite species (Chaunograptus, Yuknessia and Protohalecium), and the enteropneusts outgroup (Spartobranchus and Oesia). B - statistics.

\begin{tabular}{|c|c|c|c|c|c|c|c|c|c|c|c|c|c|c|c|c|c|c|c|c|c|c|c|c|c|c|c|c|c|c|c|c|}
\hline & 1 & & & & & & & & & 0 & 11 & 1 & 13 & 14 & 15 & $16>2>$ & 171 & 181 & 1920 & 2021 & 22 & 23 & 24 & 252 & 2627 & 2728 & 29 & 303 & 313 & 323 & 333 & \\
\hline & & & & & & & & & & & & & & & & & & & & & 1 & 2 & & & 0 & 1 & 1 & 2 & 3 & 1 & & \\
\hline & & & & & & & & & & & & & & & & & & & & & & & & & & & & & & & & \\
\hline & 3 & & & & & & & & 2 & & & 1 & & & & & & & & & & & & & & 1 & & & & & & \\
\hline & & & & & & & & & & & & 1 & & & & & & & & & & & & & & & & & & & & \\
\hline & & ? & & & & & & & 2 & & & 1 & 4 & & & & & & & & 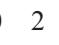 & & & & & 1 & 1 & & & & & \\
\hline & & & & & & & & & 2 & & & 1 & & 0 & & & & & ? & & & & 2 & & 0 & 1 & & & & & & \\
\hline & & & & & & 1 & & & 2 & & & 1 & 4 & 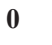 & 1 & & & & 1 & 1 & & & & & & 1 & 1 & & & & & \\
\hline & : & 8 & & & & 1 & & & 2 & . & & & $?$ & 0 & 1 & & & 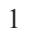 & 1 & 1 & 1 & 2 & 2 & & ( & 1 & 1 & $?$ & & & & \\
\hline & 1 & & & & 1 & 1 & & & 1,2 & 1 & 1 & 1 & 1 & 1 & 1 & & & 2 & & & & & & & & 1 & 1 & & & & & \\
\hline & 1 & & & & 1 & 1 & & & 2 & 1 & 1 & 1 & 3 & 1 & 1 & & 0 & 1 & 0 & 1 & 1 & 2 & 2 & 1 & 0 & 1 & 0 & $?$ & & & & \\
\hline & 1 & 0 & & & 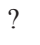 & 1 & & & 1 & 1 & 2 & 1 & 1 & 1 & 0 & & & & & & & & & & & 1 & 1 & 1,22 & 2,3 & 0 & & \\
\hline & $?$ & & & & ? & & ? & & 2 & 1 & & 1 & 2 & 1 & 0 & & & & 1 & 1 & 1 & 0 & 2 & 0 & 0 & 1 & 1 & $?$ & $?$ & ? & 0 & \\
\hline & ? & ? & ? & ? & . & 1 & $?$ & . & 3 & & 1 & 0 & 0 & 1 & 0 & 0 & & & & 1 & 1 & 0 & 2 & c & 0 & 0 & 0 & ? & $?$ & $?$ & 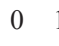 & \\
\hline & 1 & 0 & & & & 1 & 0 & & 2 & & 2 & 1 & $J$ & 1 & 0 & & & 0 & & 1 & 1 & 0 & 2 & 0 & & 1 & 0 & ? & ? & 0 & & \\
\hline & 1 & 0 & 1 & 2 & & & 0 & & 2 & 1 & 1 & 1 & 1 & 1 & 0 & & & & 1 & 1 & 1 & 0 & 1 & 0 & 1 & $\begin{array}{ll}0 & 0\end{array}$ & 1 & 2 & 0 & ) & & \\
\hline & 0 & o & & & & 0 & & & 0 & & 0 & 0 & 0 & 1 & 0 & & & & 0 & 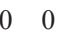 & 0 & 0 & 0 & 0 & 0 & 0 & 8 & ? & $?$ & & & \\
\hline & 0 & 0 & 0 & ( & ( & & 0 & ( & 0 & 0 & 0 & 0 & 0 & 1 & 0 & & 0 & & 0 & 1 & 1 & 0 & 0 & 0 & 0 & $\begin{array}{ll}0 & 0\end{array}$ & 0 & 0 & & & & \\
\hline & ? & ${ }^{\circ}$ & ? & & 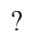 & 1 & & & ${ }^{\circ}$ & r. & 1 & 1 & ${ }^{\circ}$ & $\cdot$ & 0 & & 0 & & 1 & 1 & 1 & 1 & ? & 0 & 0 & 0 & ? & $?$ & $?$ & $?$ & & \\
\hline & $?$ & & 1 & & 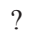 & 1 & & ? & ? & $?$ & 1 & 1 & ? & 1 & 0 & & & & 1 & 1 & 1 & 0 & 1 & 0 & & 0 & ? & 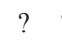 & & & & \\
\hline & 0 & 0 & 0 & 0 & & 0 & & & 0 & 0 & 8 & 0 & 0 & 0 & 0 & & 0 & 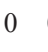 & 0 & 1 & 1 & 0 & 0 & 0 & 0 & 0 & 0 & 0 & 0 & 0 & 0 & \\
\hline & 0 & 0 & 0 & & 0 & 0 & & 0 & 0 & 0 & 0 & 0 & 0 & 0 & 0 & & 0 & 0 & 0 & 1 & 1 & 0 & 0 & 0 & $\begin{array}{ll}0 & 0\end{array}$ & 0 & 0 & 0 & 0 & 0 & 1 & \\
\hline D & & & & & ? & $?$ & & & ${ }^{\circ}$ & . & : & 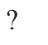 & . & 1 & $\cdot$ & 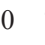 & ${ }^{\circ}$ & 0 & 0 & 10 & 1 & 1 & 1 & 0 & $\begin{array}{ll}0 & 0\end{array}$ & $0 ?$ & $?$ & $?$ & & & & \\
\hline
\end{tabular}

A

\begin{tabular}{|c|c|c|c|c|c|c|c|}
\hline & $\begin{array}{c}\text { All taxa; } \\
\text { enteropneusts } \\
\text { as outgroup }\end{array}$ & $\begin{array}{c}\text { All taxa; } \\
\text { enteropneust } \\
+ \text { Cephalodiscus } \\
\text { as outgroup }\end{array}$ & $\begin{array}{c}\text { Chaunograptus } \\
\text { excluded }\end{array}$ & $\begin{array}{c}\text { Chaunograptus } \\
+ \text { Dendrotubus } \\
\text { excluded }\end{array}$ & $\begin{array}{c}\text { Chaunograptus } \\
+ \text { Epigraptus } \\
+ \text { Epigraptus } \\
\text { excluded }\end{array}$ & $\begin{array}{c}\text { Dendrotubus } \\
+ \text { Epigraptus } \\
\text { excluded }\end{array}$ & $\begin{array}{c}\text { Chaunograptus } \\
+ \text { Epigraptus } \\
\text { excluded }\end{array}$ \\
\hline Eugraptolithina & 100 & 100 & 64 & 71 & 75 & 100 & 71 \\
\hline Tree length & 73 & 73 & 72 & 69 & 65 & 66 & 69 \\
\hline Consistency index & 0.753 & 0.753 & 0.764 & 0.783 & 0.815 & 0.803 & 0.797 \\
\hline Retention index & 0.876 & 0.876 & 0.879 & 0.885 & 0.904 & 0.899 & 0.896 \\
\hline
\end{tabular}

B

by resorption by the first thecal zooid (Mitchell et al. 2013) (0 - absent; 1 - resorption; 2 - primary);

4) Metasicular fuselli: Fusellar growth bands observed in the metasicula (distal tubular part of the sicula) (0 absent; 1 - irregular; 2 - regular zigzag suture);

5) Spiral astogeny: Coiled growth pattern of the first tube around the sicula (0 - absent; 1 - present);

6) Serial budding: Sequential zooid budding that originates from the serial stolon system and not another structure like the basal disc ( 0 - absent; 1 - present);
7) Internal autothecae in prosicula: Autothecae originates within the prosicula and not in distal regions of the sicula (0 - absent; 1 - present);

8) Stolon type: General form of the stolon $(0-$ absence; 1 - tubular; 2 - beaded; 3 - unsclerotized/not preserved);

9) Stolon position: Location of the stolon within the tube ( 0 - absent; 1 - embedded in basal wall; 2 - central; 3 - embedded in upper wall);

10) Stolon diaphragms: Globular or cup-like expansion in 
main stolon at nodes where daughter stolons branch (at the base of autotheca/bitheca); also known as vesicular diaphragms ( 0 - absent; 1 - present);

11) Budding type: Number of zooids (or its respective branching theca or stolons) budding at each division, it involves the presence of a new autothecae and sometimes bithecae ( 0 - absence; 1 - diad; 2 - triad);

12) Thecae with stolon system: Refers to the old term 'stolothecae' that was considered a type of tube enclosing stolon, for almost all dendroid-like graptolites, is the main tube of the colony. If the autotheca is recognized as the main and larger type of graptolite thecae (as it is for graptoloids), under this parameter, the stolotheca is a synonym of autotheca but as an immature form (Bulman 1970). This character is included based on the presence of a pterobranch species (Cysticamara) where the stolon is not surrounded by thecal tubes but extrathecal tissue (Kozlowski 1949), as well as Cephalodiscus and acorn worms where there is no stolon system ( 0 - absent; 1 - present);

13) Stolon location within thecorhiza: Position of stolon in the thecorhiza (a compact encrusting basal disc, similar to the creeping tubes in other graptolites) $(0-$ stolon absent; 1 - encrusting; 2 - on top of thecorhiza; 3 - diverse locations within thecorhiza; 4 - thecorhiza absent);

14) Encrusting: Type of tube growth that is sideways the surface and not upwards (as the erect tubes), this characteristic is inferred from preservation and/or presence of basal membrane; a synonym is creeping or repent: $(0-$ no; 1 - yes);

15) Erect series of interconnected thecae: Erect tubes show any type of stipe connection (see character 18), excluding erect tubes that are single $(0-$ absent; 1 present);

16) Planktic: Colonies that have a free lifestyle, inferred from the absence of encrusting tubes or in situ preservation: $(0-$ no; 1 - yes);

17) Paired dimorphic theca: Presence of paired autothecae and bithecae clearly differentiated ( 0 - absent; 1 present);

18) Stipe connection: Type of discontinuous lateral interconnection between branches [ 0 - absent; 1 - anastomosis (temporary fusion of lateral walls); 2 - dissepiments (connection by cortical material); 3 - thecal bridges (permanent, suggested after Maletz 2019b)];

19) Upright planar tubarium: Colony has a two-dimensional arrangement, excluding bushy or colonies growing upwards from their encrusting tubes, that suggest a tridimensional form $(0$ - absent; 1 - present $)$;

20) Thecal construction: Refers to the arrangement of the tubes as seen in a cross section $(0$ - irregular; 1 tubular with unshared walls; 2 - tubular with shared dorsal walls);
21) Vesicular theca: Presence of any vesicular structure along the tube, like a graptoblast (See character 26) (0 - absent; 1 - present);

22) Autothecal isolation: Degree of separation of the new autotheca from the main tube. For some dendroidlike pterobranchs, distal conical branching thecae are called metathecal/autothecal tubes, as assumed to be autotheca ( 0 - non-tubular or irregular; 1 - complete or partial; 2 - not isolated);

23) Branch condition: Type of stipe branching [0 undefined/absent; 1 - stipes possess a single thecal series; 2 - compound (single stipe with several thecal series growing along)];

24) Fusellar sutures on autothecal tubes: Type of fusellar pattern in erect tubes $(0$ - irregular or absent; 1 zigzag);

25) Autothecal coiling: Autotheca show a spiral coiling of the erect thecal tube $(0$ - absent; 1 - present);

26) Closed terminal buds: Refers to the presence of a particular enclosing structure where latent budding zooids develop. Graptoblasts are a type of flattened oval resting cyst with fusellar lines located in the stolotheca and usually observed in Crustoidea and Camaroidea. A similar, yet less specialized enclosing structure has been observed in Rhabdopleura and is coded as 'encapsulated' (See Urbanek 1983) (0 absent; 1 - encapsulated; 2 - graptoblast);

27) Conotheca: Large conical theca irregularly developed only in some tuboids ( 0 - absent; 1 - present);

28) Bithecae: Short type of theca, smaller compared with the autotheca, usually shows an alternated growth side along the stipes, present in triad budding individuals $(0$ - absent; 1 - present);

29) Spongy extrathecal mass: Spongy tissue present around some thecal walls, mostly observed in Cephalodiscus and some encrusting species $(0-$ absent; 1 - present);

30) Endocortex: Structure of the cortex (laminated cortical tissue that forms the periderm) secreted inside the fusellar tissue, produced by multiple secondary depositions of sheets and intersheet material [0 pseudocortex (intersheet material lacking fibrous elements); 1 - paracortex (intersheet material as a condensed meshwork of fibrous elements); 2 eucortex (well defined, straight and parallel fibrils) (Urbanek \& Mierzejewski 1984)];

31) Ectocortex: Structure of the cortex secreted outside or above the fusellar tissue ( 0 - absent; 1 - pseudocortex; 2 - paracortex; 3 - eucortex);

32) Vesicular sheet fabric: Material composed of electron dense, homogeneous, or very densely reticulated pellicle delimiting particular fuselli or layers (Urbanek $\&$ Towe 1974) $(0$ - absent; 1 - present);

33) Tube fibrils: Fine fibrous elements that constitute the 
thecal tubes, similar to those observed in Oesia disjuncta (Fig. 4F, Nanglu et al. 2016) (0 - absent; 1 - present);

34) Coloniality: Inferred by the presence of serial branching and the presence of stolons reported in the literature (See Landing et al. 2018) (0-absent; 1 present).

Unknown states were scored as '?' and polymorphic traits as ' $0,1,2,3$ or 4'. Missing characters under the parsimony criterion assign to taxa the character state that would be most parsimonious given its placement on the tree. Therefore, only the characters with no missing data will affect the placement of the taxa (Swofford 2002). Characters were treated as unordered and with equal weight. Analysis were run using PAUP 4.0b10 (Swofford 2002) under the assumptions of parsimony using the heuristic and branch-and-bound search algorithm by bootstrapping using 10,000 replicates. Statistics reported include tree length, consistency index, and retention index. New Technology Analyses with default parameters were also performed in TNT (Goloboff et al. 2008), and statistics including tree length and absolute and relative Bremer support values were calculated. Changes of individual characters along branches were tracked using Mesquite 3.51 (Maddison \& Maddison 2018).

\section{Systematic Paleontology}

Hemichordata Bateson, 1885

Class Pterobranchia Lankester, 1877

Subclass Graptolithina Bronn, 1849

\section{Genus Chaunograptus Hall, 1882}

Type species. - Dendrograptus (Chaunograptus) novellus Hall, 1882.

Emended diagnosis. - Minute organic theca, creeping and branching, bearing conical tubes with simple and straight apertures (Bulman 1970, Maletz \& Beli 2018).

Remarks. - The genus was initially considered a hydroid until Obut (1964) classified it as a dithecoid graptolite (Family Chaunograptidae). Mierzejewski (1986) suggested that the type species of Desmohydra (D. flexuosa) and Epallohydra (E. adhaerens) resemble that of Chaunograptus and therefore those genera should be treated as synonyms. Maletz (2014b) considered the genus as a hydrozoan based on the idea of Mierzejewski (1986). Maletz \& Beli (2018) included Chaunograptus in the family Rhabdopleuridae and we follow that decision here.

\section{Chaunograptus scandens Ruedemann, 1931}

Figure 2

1931 Chaunograptus scandens n. sp.; Ruedemann, p. 2, pl. 2, figs 4-6; pl. 4, fig. 1.

Holotype. - USNM 83484 from the Burgess Shale Member, Stephen Formation (Locality 35k Walcott).

Material. - ROM 61106, ROM 981517, ROM 58022 from the Walcott Quarry.

Description. - Tubarium consists of a narrow, straight to undulated central tube stem ranging from $55-135 \mu \mathrm{m}$ in width, $93 \mu \mathrm{m}$ average width and up to $150 \mathrm{~mm}$ length. Alternate short conical tubes typically $700 \mu \mathrm{m}$ average length, widening gradually towards the aperture from $90 \mu \mathrm{m}$ at the base to $135 \mu \mathrm{m}$. Thecae develop alternately on the stem, projecting irregularly at various angles ranging from $15-80^{\circ}$, frequently at angles of $50-60^{\circ}$. Details of the fusellar ultrastructure have not been observed.

Remarks. - Slabs contain several short fragments that suggest a continuous arrangement of a single longer colony. It is possible that the smallest tubes are part of the terminal or budding theca supporting the idea of an upward projecting epibenthic suspension feeder (Caron \& Jackson 2008). The narrow central tube can be interpreted, following the traditional use, as the prototheca that form the stipe axis and divergent metathecae. The holotype USNM 83484 also from the Stephen Formation, approaches the shortest and widest values of thecal measurements observed from the ROM specimens. One or two fragments of C. scandens are present in several slabs from this locality. Those with abundant specimens were used for this description, particularly one slab (ROM 58022) with counterparts preserved of numerous traces of possibly a single long tube (Fig. 2D). Tubarium ROM 61106 resembles that of the holotype by being closely attached to another organism, possibly a sponge, but not Tupoia lineata, as observed in the holotype (Ruedemann 1931). The ROM 981517 and ROM 58022 samples contain several specimens of C. scandens preserved in assemblage with other taxa but not attached to or found near to them. The genus Chaunograptus from the middle Cambrian Burgess Shale may represent one of the oldest colonial pterobranchs if fusellar construction can be recognized (Maletz 2013), however, due to poor preservation, especially by the lack of organic preserved material in the flat specimens and their minute size, only the outline of the colonies have been found. Rickards \& Durman (2006) proposed its taxonomic affinities to the order Dithecoidea based on Obut (1964) but it is 

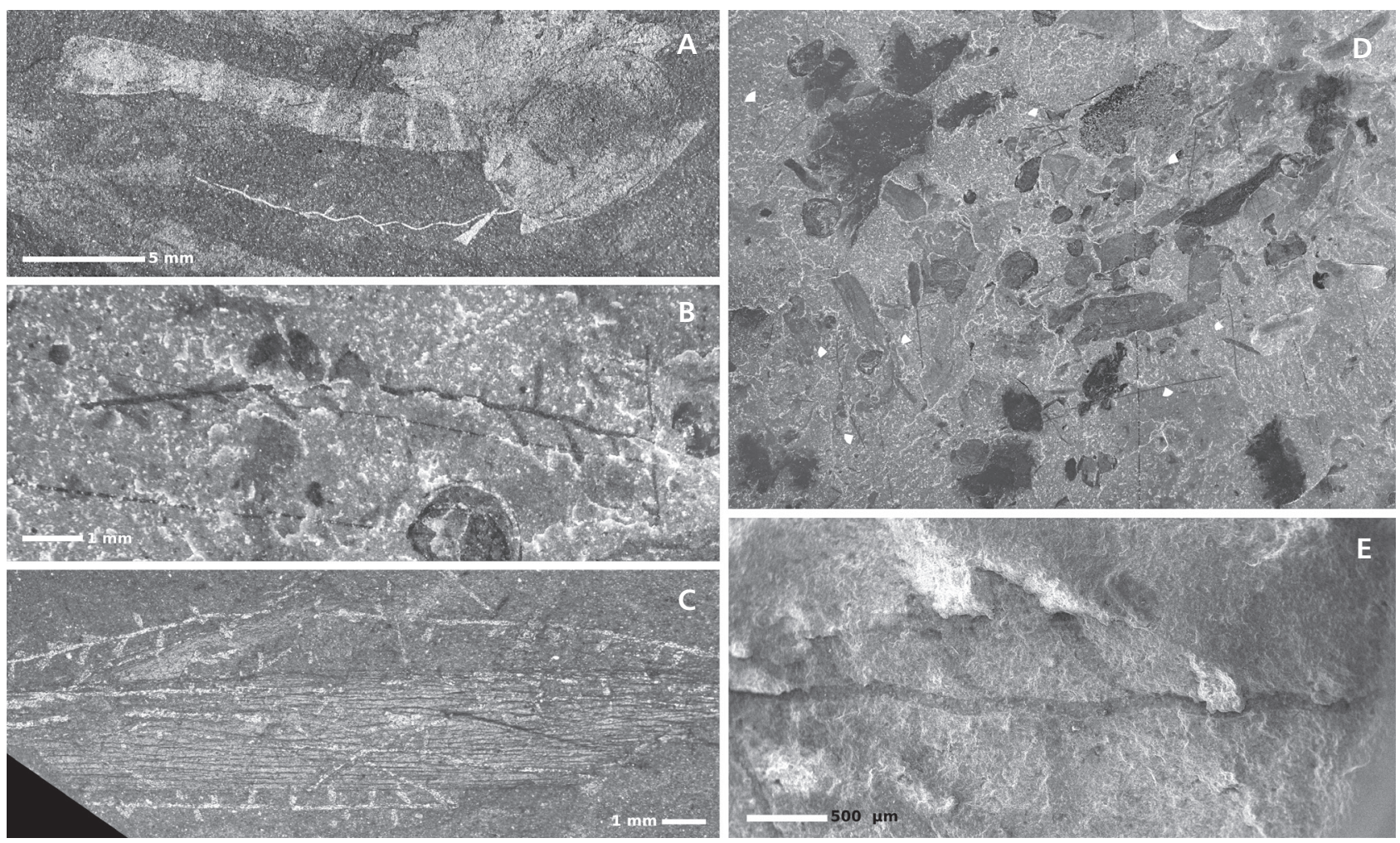

Figure 2. Chaunograptus scandens Ruedemann, 1931; A - ROM 61106, C. scandens in association with an arthropod species; B - ROM 58022 showing the two types of tubes, straight and undulated, from a possible continuous single individual; C - holotype USNM 83484 showing two individuals in association with a sponge-like fossil; D - slab with several fragments of $C$. scandens (indicated by white triangles) together with other associated fauna; E-BSE image showing the tubes and its alternate autothecal segments.

no longer a recognized order, after Maletz (2014b) reclassified some of its species into the incerta sedis family Dithecodendridae, making no reference to Chaunograptus. Maletz \& Steiner (2015) suggested that due to the straightness of the tube (that is not always consistent based on the undulated forms preserved) and the short conical thecae, C. scandens may not be related to the type species Dendrograptus (Chaunograptus) novellus, but rather to a possible erect-growing dithecoid. Maletz \& Beli (2018) regarded the genus as a member of the Rhabdopleuridae. Backscatter SEM imaging did not show any details of the fusellar sutures or stolon as organic material traces. Instead, most specimens consist of imprints in the sediment, and only the outline of the tubarium is preserved.

Occurrence. - Walcott Quarry, Fossil Ridge, Burgess Shale Member, Stephen Formation, Yoho National Park, British Columbia.

\section{Genus Yuknessia Walcott, 1919}

Figure 3

Type species. - Yuknessia simplex Walcott, 1919.
Emended diagnosis. - Isolated long, slender and slightly conical erect tubes non-interconnected, arranged in radiating clusters originated from a circular attachment structure at the base. Rarely branched erect tubes, with evidence of irregular fusellar bands (LoDuca et al. 2015a, b; Maletz \& Steiner 2015; Maletz \& Cameron 2016).

Remarks. - Yuknessia was initially classified as a tentative Chlorophyta by Walcott (1919) and further reports of the genus in the USA (Conway-Morris \& Robison 1988, Skinner 2005) and China (e.g., Hou et al. 1999, Babcock \& Zhang 2001, Guo et al. 2010, Zhao et al. 2011) supported this algal affinity. Maletz \& Steiner (2015) found fusellar patterns in a specimen from Utah using backscatter SEM and, recognizing its resemblance to Yuknessia simplex, classified it as a cephalodiscid pterobranch. LoDuca et al. (2015a) redescribed the genus as a 'benthic colonial pterobranch' based on the identification of fusellar bands and other ultrastructural details, and suggested a close resemblance to rhabdopleurid pterobranchs due to similarities in the suture patterns and budding patterns from the repent tubes, but differing by the distinct zigzag suture and absence of branching in erect tubes of Rhabdopleura. Despite these similarities, LoDuca et al. (2015a) 
did not formally identify the genus as a graptolite. Maletz \& Cameron (2016) included Yuknessia as incertae sedis in the Pterobranchia. The presence of a stolon system has not been identified, though this does not necessarily indicate its absence. It is possible that it lacks the sclerotized sheath that would favour its preservation.

\section{Yuknessia simplex Walcott, 1919}

Figure 3A

partim 1919 Yuknessia simplex n. sp.; Walcott, p. 235, pl. 54, fig. 1a [non fig. 1b, c (=Dalyia racemata)].

partim 1966 Yuknessia simplex (Walcott). - Johnson, p. 38, pl. 17, figs 1, 2 (non pl. 17, fig. $5=$ Dalyia racemata) .

non 1988 Yuknessia simplex (Walcott). - Conway-Morris \& Robison, p.16, figs 11.1-11.6 (= Yuknessia stephenensis).

1994 Yuknessia simplex (Walcott). - Briggs et al., p. 57, fig. 6.

2015 Yuknessia simplex (Walcott). - Maletz \& Steiner, p. 1094, fig. 15a-c.

2015a Yuknessia simplex (Walcott). - LoDuca et al., p. 83, figs 1.1-1.4, figs 2.4-2.9.

Holotype. - USNM 35406 from the Trilobite Beds, Campsite Cliff Shale Member, Mount Stephen, Burgess Shale Formation, Yoho National Park (Locality 14s Walcott).

Material. - ROM 62919, ROM 62920, ROM 62921 from the Trilobite Beds.

Emended diagnosis. - Tubarium bears several elongated conical tubes arrayed roughly radially around a black granular object. Slender tubes slightly flexuous ranging from 6-8 $\mathrm{mm}$ length, up to $13 \mathrm{~mm}$ long, widening distally from $0.1 \mathrm{~mm}$ at the base to $0.5 \mathrm{~mm}$ towards the aperture. Central (assumed as the repent portion) branching pattern at irregular intervals, bifurcation or interconnections not observed or possibly concealed by the dense overlapped tubes. Fusellar sutures from faint to clearly visible with an average distance of $22 \mu \mathrm{m}$. All specimens lack evidence of a stolon system (LoDuca et al. 2015a).

Remarks. - Yuknessia simplex is the type species of the genus, described by Walcott in 1919 using the holotype USNM 35406 from the Trilobite Beds and two paratypes, USNM 35407 and 35408, from the Phyllopod Bed. The three specimens show notable morphological differences that indicate two probable species. Maletz \& Steiner (2015) considered the holotype as the only specimen that fits in the description of the genus Yuknessia. LoDuca et al. (2015a) mentioned that some non-types are consistent with the dimensions of Dalyia racemata rather than $Y$. simplex, an idea also supported by Maletz \& Steiner (2015); however, a final assignment is limited by the quality of the material and it is conceivable, together with both paratypes, that they are not true pterobranchs. With the reexamination of the types made by LoDuca et al. (2015a), Yuknessia simplex is only known from the holotype and other fragmentary specimens from Mount Stephen and no definitive specimens are known from the Walcott Quarry; therefore it should be considered rare and restricted to a Burgess Shale-type locality. Maletz \& Steiner (2015) accepted a possible cephalodiscid affinity, until clear interconnections or stolon systems are observed in newly collected material.

Occurrence. - Trilobite Beds, Campsite Cliff Shale Member, Mount Stephen, Burgess Shale Formation, Yoho National Park, British Columbia.

\section{Yuknessia stephenensis LoDuca et al., 2015a}

\author{
1988 ?Yuknessia simplex (Walcott). - Conway-Morris \& \\ Robison, p. 16, figs 11.1-11.6. \\ 2015a Yuknessia stephenensis n. sp.; LoDuca et al., p. 85, \\ figs 2.1-2.3.
}

Holotype. - ROM 62918 from the Trilobite Beds, Campsite Cliff Shale Member, Mount Stephen, Burgess Shale formation, Yoho National Park (Locality 14s of Walcott).

Material. - ROM 62918 from the Trilobite Beds.

Diagnosis. - Tubarium consists of several elongated conical tubes arrayed in roughly radial fashion and emerging around a central repent area covered by overlapping tubes. Definitive branching not evident but overlaps are present. Erect tubes form slightly flexuous, from 7 to $20 \mathrm{~mm}$ in length and widening gradually distally from $\sim 0.1 \mathrm{~mm}$ at the base to a maximum of $\sim 0.8 \mathrm{~mm}$ at the straight aperture. Fuselli with strong transverse ridges with an average height of $0.032 \mathrm{~mm}$ faintly visible in BSE images. Absence of zigzag sutures, suggest the presence of full rings are present in the erect tubes. All specimens lack evidence of a stolon system (LoDuca et al. 2015a).

Remarks. - Yuknessia stephenensis was a new, true pterobranch species proposed by LoDuca et al. (2015a) to accommodate the specimens from the Trilobite Beds and all the material from the Spence and Wheeler formations of Utah (Conway-Morris \& Robison 1988), previously assigned to $Y$. simplex, based on the width differences of the erect tubes. Maletz \& Steiner (2015) referred some pterobranchs from Germany and that same material from Utah to Sphenoecium wheelerensis based 

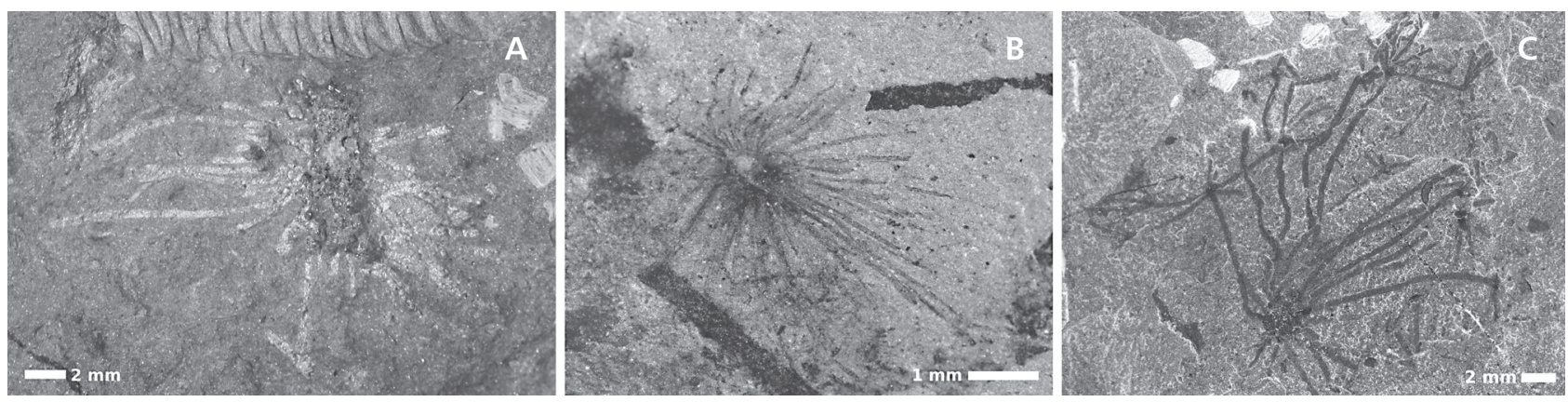

Figure 3. Yuknessia simplex Walcott, 1919; A - holotype USNM 35406 is the recognized type for the genus and Yuknessia simplex, initially described by Walcott from the Trilobite Beds; B - paratype USNM 35407, reexamination does not show a pterobranch affinity and it may possibly be classified as an alga (LoDuca et al. 2015a); C - paratype USNM 35408 shows size similarities with Dalyia racemata according to Maletz \& Steiner (2015), excluding it as a pterobranch form. Photographs of Yuknessia structural features can be found in LoDuca et al. (2015a), including the specimens here described.

on differences mostly in size, structure and erect tubes branching (apparently absent in Yuknessia). Therefore, they suggested that $Y$. stephenensis should be restricted merely to its type specimen ROM 62918. Maletz \& Steiner (2015) mentioned that Sphenoecium is typically represented by an encrusting basal region and the erect, slowly widening theca, however, several middle Cambrian pterobranchs share this same thecal morphology. It is possible that both species are alike since their differences are based on features that are not clearly distinguished and resolved. Maletz (2019a) recognized that Yuknessia and Sphenoecium may be closely related but since the proximal parts of the Yuknessia specimens are poorly preserved, it is difficult to substantiate. LoDuca et al. (2015a) mentioned that $Y$. stephenensis resembles other Cambrian pterobranch species such as Rhabdopleura obuti from Siberia (Durman \& Sennikov 1993), Rhabdotubus robustus from the Czech Republic (Maletz et al. 2005), and Archaeolafoea monegettae from Utah (LoDuca \& Kramer 2014). Detailed comparisons may invalidate these similarities and provide support for its generic designation as Yuknessia. For example, A. monegettae has an elongated growth rather than the radial arrangement characteristic of Yuknessia - although two specimens of Y. simplex from the Trilobite Beds show an axial elongated growth (LoDuca et al. 2015a). The Utah specimens are noticeably bigger, especially in terms of tube widths, compared to Yuknessia but this difference may not be the result of a taxonomical difference but ecological conditions. For example, Spence Shale and Wheeler Shale localities are $300 \mathrm{~km}$ apart, and specimens show differences in length. The holotype of Yuknessia stephenensis (ROM 62918, figs 2.1-2.3 in LoDuca et al. 2015a) does look different from Y. simplex (Fig. 3A) and its new denomination is acceptable. However, since we do not study the Utah specimens, we base our arguments on what the authors present, and decide that these Utah pterobranchs most likely belong to Sphenoecium wheelerensis. All differences between these species are merely based in morphological appearance and measurements. The holotype of $Y$. stephenensis from British Columbia, presents radial shorter and more conical thecal tubes, while the holotype of $S$. wheelerensis (Maletz \& Steiner 2015, fig. 17a-b, d-e,) from Utah presents encrusting radial, denser, longer and slowly widening theca, more similar to the Utah specimens (particularly KUMIP 204380-24382). A problem for Yuknessia species is that both holotypes are preserved in a way that the central portion of their tubarium is either concealed or dim, making difficult the understanding of how the repent or basal tubes develop, and whether the colony is radial or upright. For this reason, we only included the holotype of Y. stephenensis as the representative that occurs in British Columbia.

Occurrence. - Trilobite Beds, Campsite Cliff Shale Member, Mount Stephen, Burgess Shale Formation, Yoho National Park, British Columbia.

\section{Genus Protohalecium Chapman \& Thomas, 1936}

Type species. - Protohalecium hallianum Chapman \& Thomas, 1936.

Emended diagnosis. - Sinuously branching tubarium with terminal conical thecae dense in the distal part and increasing thecae separation proximally. Thecae narrower at their base than at the aperture. Irregular fuselli with rare zigzag sutures (Bulman 1970, Chapman \& Thomas 1936, Rickards \& Durman 2006).

Remarks. - The genus was defined by Chapman \& Thomas (1936) from fragmentary specimens collected from Knowsley East, Victoria, Australia. Quilty (1971) reported more complete and slightly bigger specimens from the Que River. Rickards \& Durman (2006) examined and photographed the type specimens and Quilty's 
material. Bulman (1970) classified the genus as incertae sedis and Maletz (2014b) and Rickards \& Durman (2006) as a hydroid. However, our observation of fuselli demonstrates that it is a graptolite.

\section{Protohalecium hallianum Chapman \& Thomas, 1936} Figure 4

1936 Protohalecium hallianum n. sp.; Chapman \& Thomas, p. 204, pl. 16, fig. 22.

1945 Protohalecium hallianum (Chapman \& Thomas). Thomas \& Henderson, p. 7, pl. 1, fig. 4.

1971 Protohalecium hallianum (Chapman \& Thomas). Quilty, p. 181, fig. 3.10; pl. 14, fig. 6.

2006 Protohalecium hallianum (Chapman \& Thomas). Rickards \& Durman, p. 60, figs 50a-c, 51.1-51.4.

Holotype. - NMV P.47748 (ex VMD No. 35972) from the locality 8 of the middle Cambrian in the Parish of Knowsley East, Victoria, Australia.

Material. - ROM 54480 and ROM 54417 from Miller Pass and TMP 2004.11.46 from Haiduk Peak.

Description. - Elongated tubarium bearing short conical thecae. Colony length 65 and $110 \mathrm{~mm}$, less than $8.5 \mathrm{~mm}$ wide. Main axis straight to sinuous in some sections, showing the appearance of slender tubes inclined to the axis but oriented in rotation, as a coiled stem. The most basal part of the main axis $\sim 0.4 \mathrm{~mm}$ wide, slightly decreasing distally to $0.15 \mathrm{~mm}$, however, this is not a strict pattern along the colony. Autothecae conical, 150-250 $\mu \mathrm{m}$ wide at the base to $350-450$ (rarely 600) $\mu \mathrm{m}$ towards the aperture. Thecal length $2.5-4.0 \mathrm{~mm}$ (average $=3.5 \mathrm{~mm}$ ). Autothecae more closely spaced in the distal part of the colony than in the proximal part where spacing ranges from 0.3 to $0.7 \mathrm{~mm}$. (Fig. 5A). Irregular fuselli are observed along the main stipe and autothecae with rare zigzag sutures (Fig. 5C). Fuselli $18-22 \mu \mathrm{m}$ in height. Other ultrastructural features not visible.

Remarks. - Most ROM 54480 measurements are at the lower end of those for TMP 2004.11.46. Total colony length differences can be explained by tubarium fragmentation. The two samples come from different localities but common biotas have been identified with other known British Columbia Burgess Shale-type deposits such as Haiduk Peak, $50 \mathrm{~km}$ southeast Mount Stephen (as in Johnston et al. 2009). The graptolites from the Duchesnay Unit in Miller Pass belong to a higher zone than those from the Walcott Quarry; however, both are similar in terms of fossil occurrences and strata positions (Johnston et al. 2009). The specimens somewhat resemble the species Archaeolafoea monegettae, which was reported from the Wheeler Shale by LoDuca \& Kramer (2014); same is the case of Yuknessia that is found in both British Columbia and Utah. The similarities are mainly in the uppermost part of the colony where autothecal branching patterns are comparable. However, these ROM and TMP specimens have a distinctive elongated sinuous growth and similar dimensions as Protohalecium hallianum Chapman \& Thomas, 1936 from Victoria, Australia. Quilty (1971) showed ink drawings of the specimens that were later photographed and more completely described by Rickards \& Durman (2006). The sinuous nature of the main axis and arrangement of the autothecae, particularly in the basal section, indicate that the colony may have been arranged helically in life (Rickards \& Durman 2006). This description represents the first identification and description of fusellar patterns in the species, and demonstrates that it is indeed a graptolite and not a hydroid. A stolon was not observed.

Occurrence. - Miller Pass, Mount Assiniboine Provincial Forrest, Stephen Formation, Burgess Shale Member and Haiduk Peak, Kootenay National Park, Duchesnay Unit, British Columbia, Canada.

Order Dendroidea, Nicholson, 1872

Family Mastigograptidae Bates \& Urbanek, 2002

\section{Genus Mastigograptus Ruedemann, 1908}

Type species. - Dendrograptus tenuiramosus Walcott, 1879.

Emended diagnosis. - Bushy, dendroid tubarium with slender, dense-walled stipe and thin-walled, distinctly widening thecae arranged in pairs. Fusellar structure with complete fusellar rings and irregular half-rings sutures. Triad budding present and autothecae/bithecae are not differentiated by size (Bulman 1970, Maletz 2014b).

Remarks. - Ruedemann (1908) established this genus based on the notable differences between the type species of the genera Mastigograptus and Dendrograptus (type is $D$. hallianus). Its taxonomic position is not clear. It was initially referred to the family Chaunograptidae by Bulman (1955), and later to the same family, but in the order Dithecoidea by Obut (1964) that included taxa that preceded dendroids. Afterwards, it was treated as a dithecoid with affinities to dendroids and considered a transitional genus between the two (Chapman et al. 1996). Rickards (1993) placed it in the order Dendroidea and then Bates \& Urbanek (2002) decided that it did not belong to the dithecoids or dendroids, and separated it into its own family Mastigograptidae and the order Mastigograptida. Maletz (2014b) referred the genus to the 

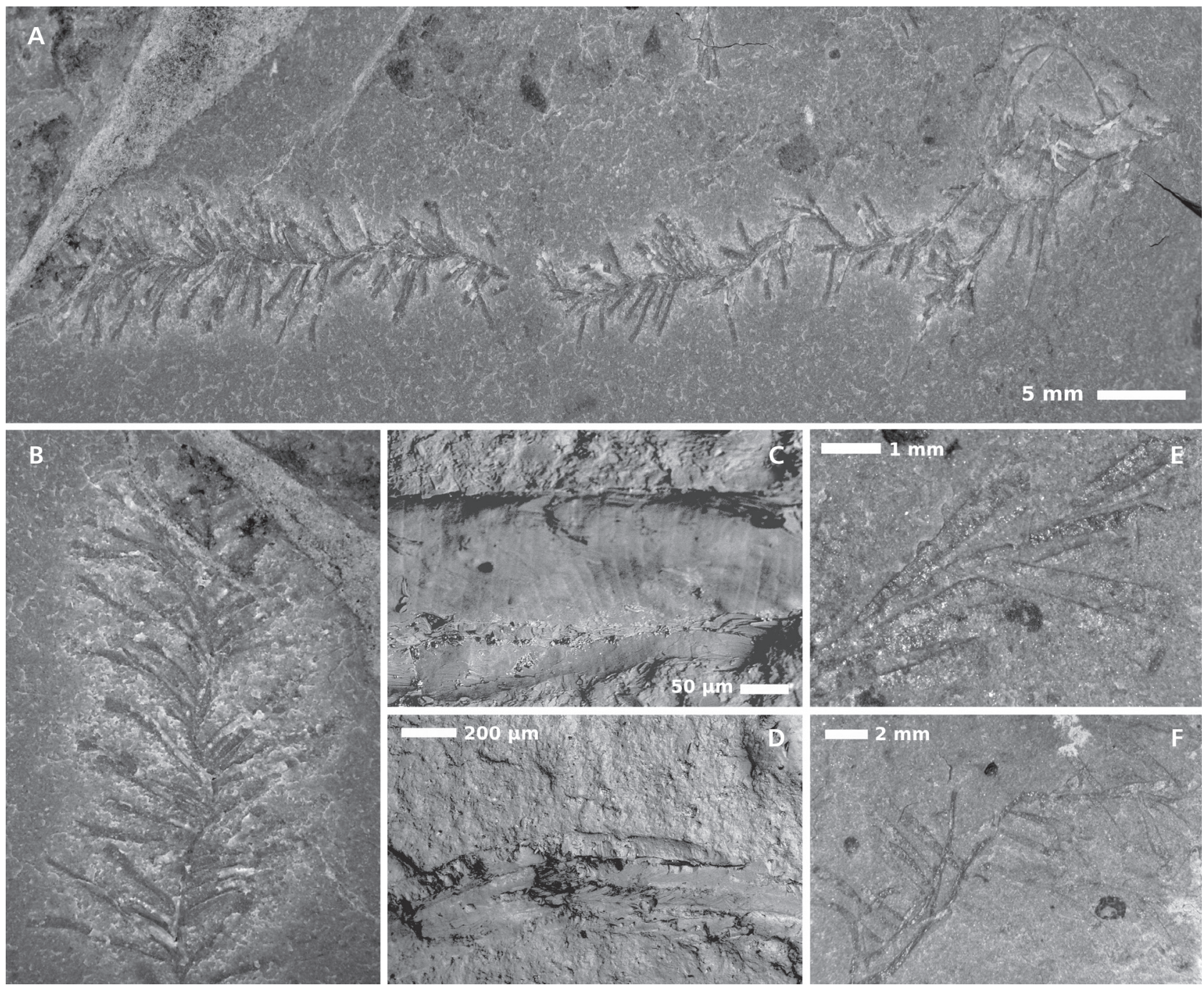

Figure 4. Protohalecium hallianum Chapman \& Thomas, 1936; A - ROM 54480 complete specimen; on the right, the basal part of the upright growing colony; $\mathrm{B}$ - detail of distal thecae showing a brush-like arrangement and no evidence of branching; $\mathrm{C}-\mathrm{SEM}$ showing regular fusellar sutures from the single-tubed autotheca; D - SEM showing fusellar sutures and twisted-tubes detail from the central axis in the mid region segment of the colony; E - TMP 2004.11.46 detail of distal thecae comparative to B; F - basal tubes to be compared with the right-most portion of A.

Order Dendroidea due to the presence of triad budding. We decided to include Mastigrograptus within the family Mastigograptidae based on their non-differentiated isolated metathecal tubes with complete fusellar rings, according to Bates \& Urbanek (2002) and Maletz (2014b) diagnosis.

\section{Mastigograptus sp. sensu Ruedemann (1947)}

Figure 5

Material. - ROM 54458, ROM 54417, and several smaller fragments from the ROM collection from Miller Pass and TMP 2004.11.7 from Haiduk Peak.

Description. - Colony about $70 \mathrm{~mm}$ long by $80 \mathrm{~mm}$ wide, branching into slender stems bearing short conical metathecae with an average width of $215 \mu \mathrm{m}$ at the base and slightly increasing to an average maximum width of $340 \mu \mathrm{m}$. Metatheca vary in length from 1.5 to $3.5 \mathrm{~mm}$. Central tube width varies between 150-200 $\mu \mathrm{m}$ and their arrangements are different depending on the position on the stipes. Upper tubes are the finest and consist of single tubes. Downwards, tubes become somewhat wider by the interconnection of older thecal compartments. Some double branching occurs at the same point, this is an indicator of triad budding, where bitheca and autotheca are not differentiated by length. Distance between thecae varies but tends to be smaller in the uppermost part of the colony. Full rings with regular fusellar sutures 15-20 $\mu \mathrm{m}$ in height, zigzag sutures rare (Fig. 4E). Single stipes frequently clustered at the tip of the colony and are more abundant at this point compared to lower stipes (Fig. 4A, B). 

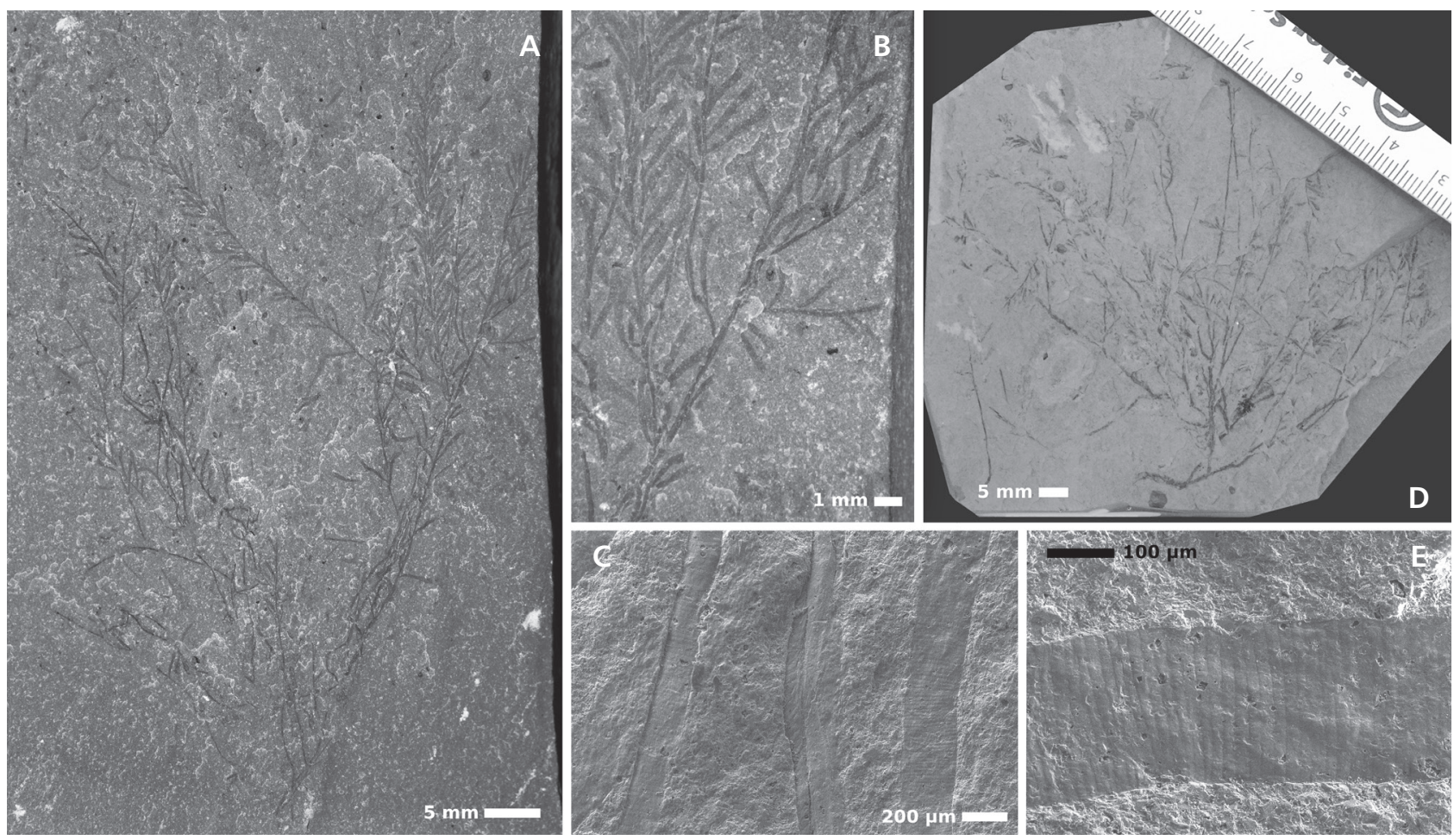

Figure 5. Mastigograptus sp. sensu Ruedemann (1947); A - ROM 54458 general view; B - ROM 54458 detail of branching theca holding conical appendages, suggesting the presence of a triad budding; $\mathrm{C}$ - three different types of tubes in the colony, all showing fuselli: single narrow, twisted, and single wide conical; D - TMP 2004.11.7 represents a less bushy colony but maintains the similar arrangement as the Miller Pass specimen (showed in $\mathrm{A}$ and $\mathrm{B})$; E - SEM image showing regular complete fusellar patterns from the uppermost part of the colony.

Colonies show an arborescent growth and most of the branching occurs at the base.

Remarks. - Metathecal lengths are difficult to measure precisely due to overlapping tubes and coverage by the matrix, however, they tend to be longer in the distal part of the colony and slightly shorter at the base. Johnston et al. (2009) reported the presence of TMP 2004.11.7 and two other graptolite fossils from the Haiduk Peak location, and mentioned their affinity to M. macrotheca but because of the absence of triad budding and inflated stolothecae - diagnostics characters according to Bates \& Urbanek (2002) - the identification was uncertain. However, the presence of three branches with a shared origin, particularly in the specimens TMP 2004.11.7, ROM 4417 and ROM 54480 (Fig. 4E), indicate the existence of this type of budding. Also, a distinctive twisted tube arrangement (Fig. 4C) can be interpreted as stolonal strands, although stolon was not observed. An undetermined species of Mastigograptus has been reported for the Burgess Shale-type Cambrian localities in Wheeler and Marjum, Utah, together with debatable Yuknessia specimens (LoDuca \& Kramer 2014). Maletz (2019a) referred to specimens from the Tyrrell Museum (see Johnston et al. 2009 and Fig. 5 herein) as possible dithecodendrids, and recognized certain morphological similarity to an Ordovician species of Mastigograptus mentioned by Andres (1961).

Occurrence. - Miller Pass, Mount Assiniboine Provincial Forest, Stephen Formation, Burgess Shale Member and Haiduk Peak, Kootenay National Park, Duchesnay Unit, British Columbia, Canada.

\section{Discussion}

The traditional classification of graptolites by Bulman (1970) recognized most benthic forms in the now disused orders Tuboidea, Camaroidea and Crustoidea and most Burgess Shale or early taxa were considered incertae sedis (e.g., Protohalecium, Mastigograptus, Chaunograptus, Sphenoecium). The revised classification of Maletz $(2014 b, 2017)$ discontinued these orders but maintained their families as uncertain taxa, and recognize the orders Dendroidea and Graptoloidea. Dendroidea includes the families Dendrograptidae, Acanthograptidae, and Mastigograptidae. Cephalodiscida was elevated to a subclass and Rhabdopleuridae is an incertae familiae. Mitchell et al. (2013), Maletz (2014b), and this phylo- 
genetic analysis reject the Bulman (1970) hypothesis that Cephalodiscus and Rhabdopleura are sister groups, and reject the Rickards \& Durman (2006) phylogeny that grouped Cephalodiscus with fossil graptolites.

Mitchell et al. (2013) employed a character list similar to that of Rickards \& Durman (2006), but excluded all genera that were presumably redundant with other taxa or for which little morphological information was available. They placed Cephalodiscus as a paraphyletic outgroup, based on initial unrooted trees analysis, and because the tube-building enteropneusts were unknown at that time. The Burgess Shale enteropneusts Spartobranchus tenuis (Caron et al. 2013) and Oesia disjuncta (Nanglu et al. 2016) were tubicolous, suggesting that tubes are a hemichordate plesiomorphy, elaborated in the pterobranchs line, and lost in the crown group acorn worms (Caron et al. 2013, Nanglu et al. 2016, Cameron 2018).
The tubes of Oesia disjuncta were porous, made of woven fibres, and previously known as the alga Margaretia dorus (Conway Morris et al. 1988, Nanglu et al. 2016). We conducted one analysis using the tubicolous acorn worms as a monophyletic outgroup to the graptolites, and a second with acorn worms plus Cephalodiscus as outgroup taxa, but found no difference in tree shape or statistics, because the alternate outgroups did not produce a polarization of characters. Cephalodiscus is distinct from the graptolites in its pseudocolonial habit that lacks connecting stolons, the absence of a larval prosicula, and the relatively simple ultrastructural details of the tube walls (Gonzalez \& Cameron 2012).

The genus Cephalodiscus is divided into four subgenera corresponding to different types of organization of the coenecium (Ridewood 1920, Markham 1971). The zooids of Orthoecus and Idiothecia live in individual
A
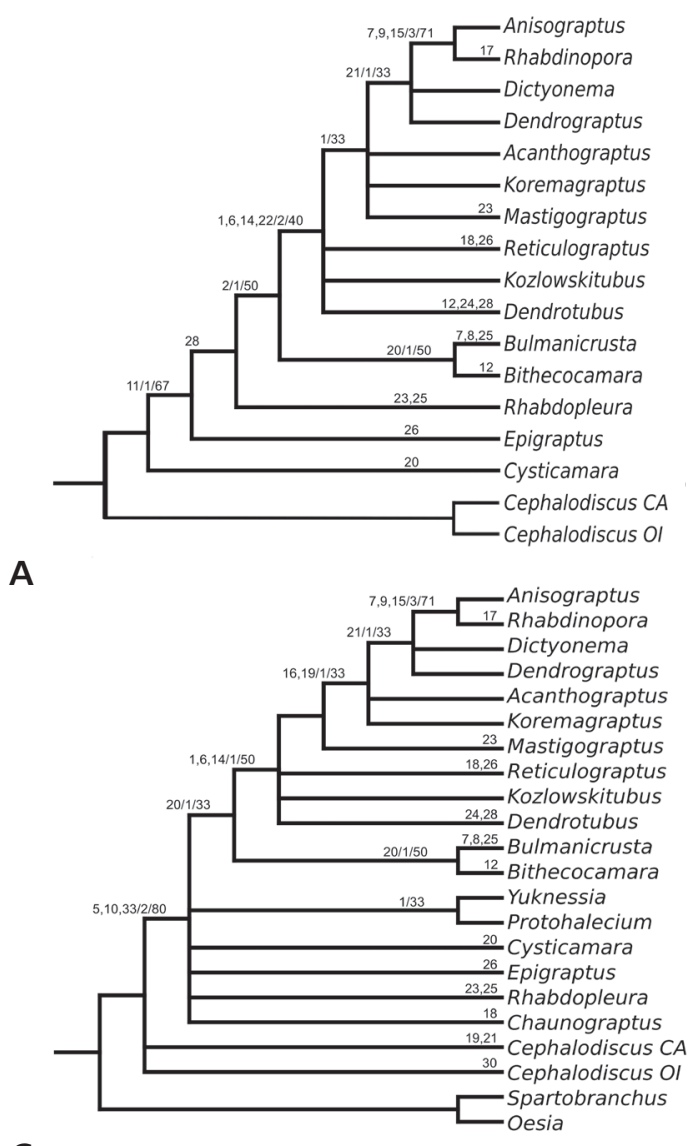

C

Figure 6. Cladograms showing the phylogenetic relationships within living and fossil pterobranch genera. $\bullet A-$ strict consensus of 4 equally parsimonious trees from a new technology analysis in TNT including only the same taxa as Mitchell et al. (2013) and no Burgess Shale genera. $\bullet$ B strict consensus of 54 equally parsimonious trees from a branch and bound analysis in PAUP considering all taxa. The heuristic analysis produces 52 equally parsimonious trees with a 52\% bootstrap value that supports the node of Dendrograptus as the sister group of the Graptoloida (Anisograptus and Rhabdinopora); the remaining branches are supported $100 \% \cdot \mathrm{C}$ - strict consensus of 6 equally parsimonious trees from a new technology analysis in TNT including all taxa. $\bullet \mathrm{D}$ - selected strict consensus cladogram of the 6 equally parsimonious trees from the previous analysis that best represents all the relationships from all the trees obtained. Numbers above the nodes and branches represent the synapomorphic characters at that branch followed by the Bremer support values and the relative Bremer support values. Branches where only one value is showed refer to the synapomorphic characters. 
tubes (Harmer 1905, Lankester 1905, Andersson 1907, John 1931). The subgenus Cephalodiscus (Harmer 1905, Andersson 1907, Johnston \& Muirhead 1951, Bayer 1962, Emig 1977) lacks individual tubes. Zooids can move freely inside a common cavity that opens to the outside through ostia placed along or at the end of the branched structure of the coenecium. Acoelothecia includes the single species $C$. kempi, whose coenecium also lacks a tubular cavity, instead composed of a network of spines welded to each other (John 1931). Therefore, Orthoecus and Idiothecia form a clade that is sister to Cephalodiscus and Acoelothecia. Combined nuclear $18 \mathrm{~S}$ rDNA and mitochondrial 16S rDNA phylogeny of cephalodiscids (Cannon et al. 2013) support these two sister clades, though which pair might represent the ancestral state is unknown. Only two characters regarding thecal arrangement differ between them (characters 20 and 22), and three others are uncertain for Cephalodiscus and Acoelothecia (characters 30-32, related to the cortex). Zooid characteristics of Cephalodiscus may provide more characters to polarize this clade. Despite the lack of resolution among cephalodiscids (Fig. 6), our analyses are congruent with previous studies that position them as sister group to the graptolites (Mitchell et al. 2013, Maletz 2014b).

Our analyses support the hypothesis that Rhabdopleura is an extant member of the Graptolithina, distinct from the living pterobranch Cephalodiscus (Mitchell et al. 2013, Maletz 2014b). We add little to the debate regarding the exact position of Rhabdopleura among these early forms (Rickard \& Durman 2006, Mitchell et al. 2013, Maletz, 2014b, Beli et al. 2018), because its position is variable, or unresolved (Fig. 6C) depending on the analyses. The only clear conclusion that can be made is that Rhabdopleura appears to occupy an important transitionary position between the basal group and the derived Eugraptolithina, characterized by a prosicula with a helical line (characters 1 and 2) (Mitchell et al. 2013).

Though little new morphological information was obtained for the Burgess Shale Protohalecium hallianum, it was included in the analyses to observe its relationship to other graptolites. In some phylogenies (Fig. 6C, D), Yuknessia and Protohalecium are sister taxa based on an encrusting habit and a simple, isolated and planar tubarium with zigzag fusellar sutures (characters 14, 19, 20, 22, 24 , respectively). The encrusting growth (character 13) and the recognition of fuselli (character 23) distinguish this clade from Chaunograptus, where these features are unknown. This grouping remains tenuous, however, because the strict consensus branch and bound tree (Fig. 6B) placed Chaunograptus and Protohalecium as sister taxa, in a trichotomy with Yuknessia and Rhabdopleura. The encapsulated terminal bud of Rhabdopleura is an autapomorphy that collapses the branch with other genera
(Fig. 6B, C). These different evolutionary hypotheses for the basal taxa are due to differences in the algorithm and especially the default collapsing conditions. For example, TNT eliminates any branch for which the minimum possible length is zero (Goloboff et al. 2008), while PAUP retains a branch if it is supported by at least one mostparsimonious reconstruction of the ancestral states, for at least one character (Swofford 2002). The TNT criteria are stricter, which explains the fewer trees obtained and more collapsed branches (Fig. 6C) compared to results from PAUP (Fig. 6B).

Cysticamara occupies a phylogenetic position inbetween Cephalodiscus and graptolites in most tree constructions (excluding Fig. 6D). Historically, it was considered a camaroid because it has diad budding (no bithecae) (characters 11 and 28) and a vesicular theca (character 21) that it shares with crustoids (Kozlowski 1949). This unique character unified Bulmanicrusta, Bithecocamara and Cysticamara in the Rickards \& Durman (2006) phylogeny. Unique to Cysticamara is a spongy extrathecal mass that surrounds the stolons embedded in the upper wall, meaning that it is not surrounded by a true stolotheca (character 12), a possible primitive character state (Kozlowski 1949). By contrast, Cysticamara exhibits derived graptolite character states like erect autothecal tubes and stolon diaphragms (character 10). Our knowledge of Cysticamara is mostly based on Kozlowski (1949) and since it may represent one of the very earliest graptolite forms, an in-depth reexamination may fill in some missing character states.

Bulmanicrusta and Bithecocamara are sister taxa even though they were classically considered crustoids and camaroids, respectively (Bulman 1970). Bithecocamara is coded here with triad budding as it has bithecae, not a typical characteristic for the diad budding of the cysticamarids, yet the presence of bithecae in some species has been noted by Kozlowski (1949). This budding type instead of representing a main difference may be a trait that unites these two taxa, despite the differences in stolon type and position (characters 8 and 9) or the presence of graptoblast (character 26). The phylogenetic analysis only included one species of each group because information about their representative species is incomplete. Possibly, camaroids and crustoids are a single group that shares the presence of a vesicular theca (character 21) (Maletz 2014b).

Because Epigraptus and Dendrotubus possess several homoplastic traits (e.g., Epigraptus has bithecae, which is not typical for tuboid graptolites), Mitchell et al. (2013) excluded these graptolites singly from some analyses in order to gauge the constraints on their phylogenetic position. The cladogram that lacks Burgess Shale taxa (Fig. 6A), placed Epigraptus and Cysticamara as intermediate forms between Cephalodiscus and Rhabdopleura and 


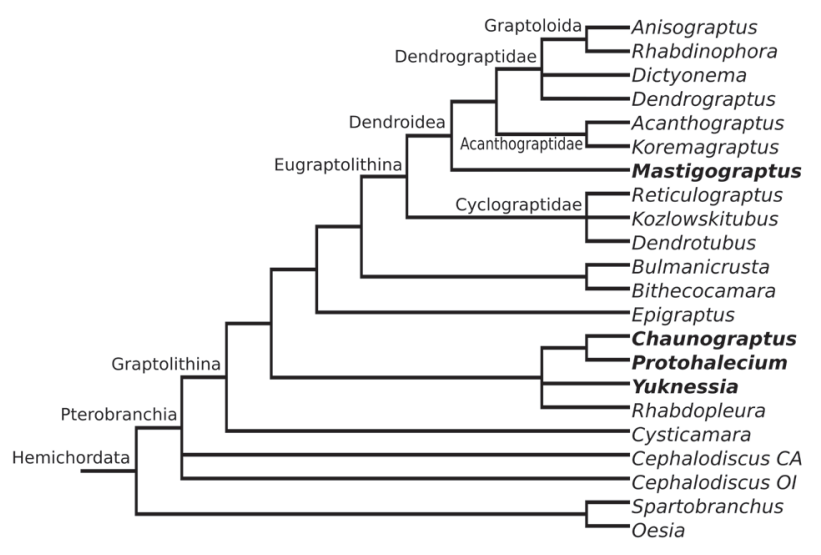

Figure 7. Strict consensus tree from a heuristic analysis in PAUP of 54 equally parsimonious trees including all 22 taxa showing in each node shows their recognized taxonomic level based on the classification of Maletz (2014b), and Mitchell et al. (2013) who recognize the infraclass Eugraptolithina.

the branch to Dendrotubus at a higher position in the tree within the Eugraptolithina. The exclusion of Epigraptus and Dendrotubus, separately and in combination with Chaunograptus, produced poorly resolved trees with lower support.

Acanthograptus and Koremagraptus are grouped by the presence of a compound branch condition (character 23) showing an anastomosed pattern (character 18). A triad of paired dimorphic thecae with shared dorsal walls defines this branch plus the early planktic genera. Maletz (2014b) included these two taxa within the family Acanthograptidae.

The genus Dictyonema, which traditionally belonged in the family Dendrograptidae, is considered central to understand the origin of planktic graptolites with the genus Rhabdinopora (Erdtmann 1982, Cooper et al. 2012, Maletz 2014b). Strict consensus trees (Fig. 6A-C) show a polytomy with Dendrograptus and Dictyonema regarding their relationship to the Graptoloidea (Rhabdinopora and Anisograptus). Maletz (2019b) reexamination of Silurian type specimens, placed Dictyonema in the family Acanthograptidae, based on a tubular theca on compound stipes (character 23) and the absence of true dissepiments as stipe connections (character 18). This is not completely supported by the present analysis, as the phylogenetic position of the genus remains unresolved, but closer to the planktic forms and not within the node that groups the acanthograptids (Fig. 6A-C). Here the addition of thecal bridges as a character state for character 18 and the presence of compound stipes in the character matrix, produced the collapsed node of Dictyonema and Dendrograptus but maintained the same phylogenetic relationship with the planktic taxa.

Changes from a benthic to a planktic habitat are mostly related to modifications in the proximal part of the colony, where the initial zooid constructs the first thecal tube, or sicula, which change may have been driven by the loss of the encrusting habit (character 14). The sicula of planktic graptolites tends to develop a caudal prosicula (character 1 ; instead of the vesicular shape), and the helical line (character 2) becomes more common. The prothecal portion of the first asexually produced theca, which houses the beginning of the stolon, initiated in a more proximal position within the sicula (character 7) and the central stolon changes from mainly tubular to unsclerotized (character 8), bearing stolon diaphragms (character 10). This contributed to the predominance of a triad budding type with paired dimorphic thecae in the most derived forms (characters 11 and 17), presenting complex stipe connections (character 15) that maintain autothecal tubes that are not completely isolated (character 22).

Graptolites from the Burgess Shale of Canada represent some of the earliest and poorly known forms. Details of the zooids are completely absent and features of the tubes, derived from flattened, poorly preserved, and often fragmented specimens, are also often not satisfactorily revealed. This lack of characters makes it a challenge to establish a robust phylogeny for the species, though their basal position within the Graptolithina is now evident (Fig. 7). With the exception of Mastigograptus, the Burgess Shale graptolites are closely affiliated with the graptolite Rhabdopleura. Following the taxonomic revision of Maletz (2014b), our analysis places Mastigograptus as an early member of the Dendroidea. This result indicates that graptolites had already undergone substantial evolutionary diversification by the mid Cambrian. Indeed, taxonomic revisions and phylogenetic analyses such as this one are key to revealing early hemichordate evolution. Most important, however, is the discovery of new pterobranch specimens from Burgess Shale-type deposits, particularly those that are rich in sessile organisms (Johnston et al. 2009, Caron et al. 2010, Zhao et al. 2013).

\section{Acknowledgements}

We thank J.B. Caron (Royal Ontario Museum) and curatorial staff for allowing access to the collection and assistance with the electron microscopy. To the Royal Tyrrell Museum for the loan of some graptolite specimens. Special thanks to Jörg Maletz and our reviewers, Michael J. Melchin and Charles E. Mitchell for their valuable comments and suggestions.

\section{References}

Andersson, K. 1907. Die Pterobranchier der schwedischen Sudpolar Expedition 1901-1903. Wissenchaft Ergebnisse

Schwedische Studpolar-Expedition 5, 1-122.

ANDRES, D. 1961. Die Struktur von Mastigograptiden aus einem 
ordovizischen Geschiebe Berlins. Neues Jahrbuch für Geologie und Paläontologie 12, 636-647.

BABCOCK, L.E. \& ZhANG, W.T. 2001. Stratigraphy, paleontology, and depositional setting of the Chengjiang Lagerstätte (lower Cambrian), Yunnan, China, 66-86. In Peng, S.C., BABCock, L.E. \& ZHU, M.Y. (eds) Cambrian of South China. University of Science and Technology of China Press, Hefei.

Bapst, D.W., Bullock, P.C., Melchin, M.J., Sheets, H.D. \& Mitchell, C.E. 2012. Graptoloid diversity and disparity became decoupled during the Ordovician mass extinction. Proceedings of the Natural Academy of Sciences 109(9), 3428-3433. DOI 10.1073/pnas.1113870109

Bates, D.E.B. \& Urbanek, A. 2002. The ultrastructure, development, and systematic position of the graptolite genus Mastigograptus. Acta Palaeontologica Polonica 47(3), 45-458.

BATESON, W. 1885. The later stages in the development of Balanoglossus kowalevskii, with a suggestion as to the affinities of the Enteropneusta. Quarterly Journal of Microscopical Science 25, 81-122.

BAYER, F.M. 1962. A new species of Cephalodiscus (Hemichordata: Pterobranchia), the first record from the tropical Western Atlantic. Bulletin of Marine Science of the Gulf and Caribbeans 12, 306-312.

Beli, E., Aglieri, G., Strano, F., Maggioni, D., Telford, M.J., Piraino, S. \& Cameron, C.B. 2018. The zoogeography of extant rhabdopleurid hemichordates (Pterobranchia: Graptolithina), with a new species from the Mediterranean Sea. Invertebrate Systematics 32(1), 100-110. DOI $10.1071 /$ IS17021

Bengtson, S. \& Urbanek, A. 1986. Rhabdotubus, a Middle Cambrian rhabdopleurid hemichordate. Lethaia 19, 293-308. DOI 10.1111/j.1502-3931.1986.tb00743.x

Briggs, D.E.G., Erwin, D.H. \& Collier, F.J. 1994. The fossils of the Burgess Shale. 238 pp. Smithsonian Institution Press, Washington \& London.

BronN, H.G. 1849. Handbuch der Geschichte der Natur. Dritter Band, Zweite Abtheilung. II. Theil: Organisches Leben (Schluß). Index palaeontologicus oder Ueberblick der bis jetzt bekannten fossilen Organismen. 1106 pp. Schweizerbart, Stuttgart. DOI 10.5962/bhl.title.102095

Bulman, O.M.B. 1955. Part V: Graptolithina. In Moore, R.C. (ed.) Treatise on Invertebrate Paleontology. The Geological Society of America and the University of Kansas, US.

Bulman, O.M.B. 1970. Part V: Graptolithina with sections on Enteropneusta and Pterobranchia. Treatise on Invertebrate Paleontology. 163 pp. The Geological Society of America and the University of Kansas, US.

Cameron, C.B. 2018. Treatise on Invertebrate Paleontology, Part V, Chapter 2, Class Enteropneusta: Introduction, Morphology, Life Habits, Systematic Descriptions, and Future Research. Treatise Online 109, 1-22.

Cameron, C.B., Garey, J. \& Swalla, B. 2000. Evolution of the chordate body plan: New insights from phylogenetic analyses of deuterostome phyla. Proceedings of the Natural Academy of Science 97(9), 4469-4474.

DOI 10.1073/pnas.97.9.4469
Cannon, J.T., Swalla, B.J., \& Halanych, K.M. 2013. Hemichordate molecular phylogeny reveals a novel cold-water clade of harrimaniid acorn worms. The Biological Bulletin 225, 194-204. DOI 10.1086/BBLv225n3p194

CAron, J.B. \& JACkson, D.A. 2008. Paleoecology of the Greater Phyllopod Bed community, Burgess Shale. Palaeogeography, Palaeoclimatology, Palaeoecology 258, 222-256.

DOI 10.1016/j.palaeo.2007.05.023

Caron, J.B., Gaines, R., Mangano, G., Streng, M. \& Daley, A. 2010. A new Burgess Shale-type assemblage from the "thin" Stephen Formation of the Southern Canadian Rockies. Geology 38, 811-814. DOI 10.1130/G31080.1

Caron, J.B., Conway-Morris, S. \& Cameron, C.B. 2013. Tubicolous enteropneusts from the Cambrian. Nature 7442 , 503-506. DOI 10.1038/nature12017

Chapman, F. \& Thomas, D.E. 1936. The Cambrian hydroids of the Heathcote and Monegeeta districts. Proceedings of the Royal Society of Victoria 48, 193-212.

Chapman, A.J., Durman, P.N. \& Rickards, R.B. 1996. A provisional classification of the graptolite Order Dendroidea. Paläontologische Zeitschrift 70, 189-202. DOI 10.1007/BF02988277

Conway-Morris, S. \& Robison, R.A. 1988. More soft-bodied animals and algae from the Middle Cambrian of Utah and British Columbia. The University of Kansas Paleontological Contributions 122, 1-48.

Cooper, R.A., Rigby, S., Loydell, D.K. \& Bates, D.E.B. 2012. Palaeoecology of the Graptoloidea. Earth-Science Reviews 112, 23-41. DOI 10.1016/j.earscirev.2012.01.001

Durman, P.N. \& Sennikov, N.V. 1993. A new rhabdopleurid hemichordate from the Middle Cambrian of Siberia. Palaeontology 36, 283-296.

Emig, C.C. 1977. Sur une nouvelle espèce de Cephalodiscus, C. (C.) caliciformis n. sp. (Hemichordata, Pterobranchia), récoltée à Madagascar. Bulletin du Museum National d'Histoire Naturelle 3e série 493, 1077-1082.

ERdTMAnN, B.D. 1982. A reorganization and proposed phylogenetic classification of planktic Tremadoc (early Ordovician) dendroid graptolites. Norsk Geologisk Tidsskrift 62(2), 121-145.

Goloboff, P.A., Farris, J. \& Nixon, K.C. 2008. TNT, a free program for phylogenetic analysis. Cladistics 24, 774-786. DOI 10.1111/j.1096-0031.2008.00217.x

Gonzalez, P. \& Cameron, C.B. 2012. Ultrastructure of the coenecium of Cephalodiscus (Pterobranchia, Hemichordata). Canadian Journal of Zoology 90, 1261-1269. DOI 10.1139/z2012-096

Guo, J., Li, Y. \& Shu, D. 2010. Fossil macroscopic algae from the Yanjiahe Formation, Terreneuvian of the Three Gorges area, South China: Acta Palaeontologica Sinica 49, 336-342.

Hall, J. 1882. Descriptions of the species of fossils found in the Niagara Group at Waldron, Indiana. Indiana Department of Geology and Natural History, 11 th Annual Report, 217-345.

Harmer, S.F. 1905. The Pterobranchia of the Siboga Expedition with an account of other species. Siboga Expedition Monograph 26, 1-133. DOI 10.5962/bhl.title.11734 
Harvey, T.H.P., Ortega-Hernández, J., Lin, J.P., Zhao, Y. \& Butterfield, N.J. 2012. Burgess Shale-type microfossils from the middle Cambrian Kaili Formation, Guizhou Province, China. Acta Palaeontologica Polonica 57(2), 423-436. DOI 10.4202/app.2011.0028

Hou, X.G., Bergström, J., Wang, H.F., FenG, X.H. \& Chen, A.L. 1999. The Chengjiang Fauna: Exceptionally Well-Preserved Animals from 530 Million Years Ago. 170 pp. Yunnan Science and Technology Press, Kunming.

Hou, X.G., Aldridge, R.J., Siveter, D.J., Siveter, D.J., WilLiams, M., Zalasiewicz, J. \& MA, X.Y. 2011. An early Cambrian Hemichordate Zooid. Current Biology 21, 612-616. DOI 10.1016/j.cub.2011.03.005

Hu, S., Erdtmann, B.-D., Steiner, M., Zhang, Y., Zhao, F., Zhang, Z. \& HAN, J. 2018. Malongitubus: a possible pterobranch hemichordate from the early Cambrian of South China. Journal of Paleontology 92(1), 26-32. DOI 10.1017/jpa.2017.134

JefFeries, R.P.S. 1986. The Ancestry of the Vertebrates. 376 pp. British Museum (Natural History) and Cambridge University Press, London.

John, C.C. 1931. Cephalodiscus. Discovery Reports 3, 223-260.

Johnson, J.H. 1966. A review of Cambrian algae. Quarterly of the Colorado School of Mines 61, 1-162.

Johnston, T.H. \& MuirheAd, N.G. 1951. Cephalodiscus. Reports BANZ Antarctic Research Expedition (B) 1, 91-120.

Johnston, K.J., Johnston, P.A. \& Powell, W.G. 2009. A new, Middle Cambrian, Burgess Shale-type biota, Bolaspidella Zone, Chancellor Basin, southeastern British Columbia. Palaeogeography, Palaeoclimatology, Palaeoecology 277, 106-126. DOI 10.1016/j.palaeo.2009.02.015

KirJanov, V. 1968. Paleontology and stratigraphy of the Baltic deposits in the Volhyn-Podolia. 5-27. In KarandievskiY, V., Ishenko, T. \& KirJanov, V. (eds) Paleontology and Stratigraphy of the Lower Paleozoic of Volhyn-Podolia. Naukova Dumka, Kiev.

Kozlowski, R. 1949. Les graptolithes et quelques nouveaux groupes d'animaux du Tremadoc de la Pologne. Palaeontologica Polonica 3, 1-330.

Kozlowski, R. 1966. On the structure and relationships of graptolites. Journal of Paleontology 40(3), 489-501.

Landing, E., Antcliffe, J.B., Geyer, G., Kouchinsky, A., Bowser, S.S. \& ANDREAS, A. 2018. Early evolution of colonial animals (Ediacaran Evolutionary Radiation-Cambrian Evolutionary Radiation-Great Ordovician Biodiversification Interval). Earth-Science Reviews 178, 105-135.

DOI 10.1016/j.earscirev.2018.01.013

LANKESTER, E.R. 1877. Notes on the embryology and classification of the animal kingdom; comprising a revision of speculations relative to the origin and significance of the germlayers. Quarterly Journal of Microscopical Science 17, 339-454.

LANkESTER, E.R. 1905. On a new species of Cephalodiscus (C. nigrescens) from the Antarctic ocean. Proceedings of the Royal Society of London 76, 400-402.

DOI 10.1098/rspb.1905.0036

LoDuca, S.T. \& Kramer, A. 2014. Graptolites form the Wheeler and Marjum Formations (Cambrian, Series 3) of Utah. Journal of Paleontology 88(2), 403-410. DOI /10.1666/12-096

LoDuca, S.T., Caron, J.B., Schiffbauer, J.D., Xiao, S., KraMER, A. 2015a. A reexamination of Yuknessia from the Cambrian of British Columbia and Utah. Journal of Paleontology 89(1), 82-95. DOI 10.1017/jpa.2014.7

LoDuca, S.T. Wu, M., Zhao, Y., Xiao, S., Schiffbauer, J.D., CARON, J.B. \& BABCOCK, L. 2015b. Reexamination of Yuknessia from the Cambrian of China and first report of Fuxianospira from North America. Journal of Paleontology 89(6), 899-911. DOI 10.1017/jpa.2016.3

Maddison, W.P. \& Maddison. D. 2018. Mesquite: a modular system for evolutionary analysis. Version 3.51. www. mesquiteproject.org

Maletz, J. 2013. Hemichordata (Pterobranchia, Enteropneusta) and the fossil record. Palaeogeography, Paleoclimatology, Palaeoecology 398, 16-27.

DOI 10.1016/j.palaeo.2013.06.010

MaLetz, J. 2014a. Graptolite reconstructions and interpretations. Paläontologische Zeitschrift 89, 271-286.

DOI 10.1007/s12542-014-0234-4

Maletz, J. 2014b. The classification of the Pterobranchia (Cephalodiscida and Graptolithina). Bulletin of Geosciences 89(3), 477-540. DOI 10.3140/bull.geosci.1465

Maletz, J. 2017. Graptolite Paleobiology. 336 pp. WileyBlackwell, UK. DOI 10.1002/9781118515624

Maletz, J. 2019a. Tracing the evolutionary origins of the Hemichordata (Enteropneusta and Pterobranchia). Paleoworld 28, 58-72. DOI 10.1016/j.palwor.2018.07.002

Maletz, J. 2019b. Dictyonema Hall and its importance for the evolutionary history of the Graptoloidea. Palaeontology 62(1), 151-161. DOI 10.1111/pala.12394

Maletz, J. \& Beli, E. 2018. Part V, Second Revision, Chapter 15: Subclass Graptolithina and incertae sedis Family Rhabdopleuridae: Introduction and Systematic Descriptions. Treatise Online 101, 1-14. DOI 10.17161/to.v0i0.7053

Maletz, J. \& Cameron, C.B. 2016. Part V, Chapter 3: Introduction to the class Pterobranchia Lankester, 1877. Treatise Online 82, 1-15. DOI 10.17161/to.v0i0.6476

Maletz, J. \& Gonzalez, P. 2017. Part V, Chapter 14: Order Cephalosdiscida: Introduction and systematic descriptions. Treatise Online 100, 1-8. DOI 10.17161/to.v0i0.6674

Maletz, J. \& Steiner, M. 2015. Graptolite (Hemichordata, Pterobranchia) preservation and identification in the Cambrian Series 3. Palaeontology 58(6), 1073-1107. DOI 10.1111/pala.12200

Maletz, J., Steiner, M. \& FatKa, O. 2005. Middle Cambrian pterobranchs and the question: What is a graptolite? Lethaia 38, 73-85. DOI 10.1080/00241160510013204

Maletz, J., Bates, D.E.B., Brussa, E.D., Cooper, R.A., Lenz, A.C., Riva, J.F., Toro, B.A. \& Zhang, Y. 2014. Part V, Revision 2, Chapter 12: Glossary of the Hemichordata. Treatise Online 62, 1-23. DOI 10.17161/to.v0i0.4710

Maletz, J., Lenz, A.C. \& Bates, D.E.B. 2016. Part V, Second Revision, Chapter 4: Morphology of the pterobranch tubarium. Treatise Online 76, 1-63.

DOI $10.17161 /$ to.v0i0.5727 
Markham, J.C. 1971. The species of Cephalodiscus collected during operation Deep Freeze, 1956-1959. Antarctic Research Series 17, 83-110. DOI 10.1029/AR017p0083

Mierzejewski, P. 1986. Ultrastructure, taxonomy and affinities of some Ordovician and Silurian organic microfossils. Acta Palaeontologica Polonica 47, 129-220.

Mierzejewski, P. 1988. Encrusting graptolites from the Mulde Beds of Gotland. Acta Palaeontologica Polonica 33(3), 261-266.

Mitchell, C.E., Melchin, M., Cameron, C.B. \& Maletz, J. 2013. Phylogenetic analysis reveals that Rhabdopleura is an extant graptolite. Lethaia 46, 34-56.

DOI 10.1111/j.1502-3931.2012.00319.x

Nanglu, K., Caron, J.B., Conway-Morris, S. \& Cameron, C.B. 2016. Cambrian suspension-feeding tubicolous hemichordates. BMC Biology 14, art. 56.

DOI 10.1186/s12915-016-0271-4

Nicholson, H.A. 1872. A monograph of the British Graptolitidae. 133 pp. Blackwood \& Sons, Edinburgh \& London.

OBut, A.M. 1964. Order Hemichordata. In OrLov, Y.A. (ed.) Osnovy Palaeontologii. Nedra Press, Moscow.

Quilty, P.G. 1971. Cambrian and Ordovician dendroids and hydroids of Tasmania. Journal of the Geological Society of Australia 17(2), 171-189. DOI 10.1080/00167617108728732

Rickards, R.B. 1993. Graptolithina, 537-542. In Benton, M.J. (ed.) The Fossil Record. Chapman \& Hall, London.

Rickards, R.B. \& Durman, P.N. 2006. Evolution of the earliest graptolites and other hemichordates, 5-92. In BAssett, M. \& Deisler, V. (eds) Studies in Paleozoic paleontology. National Museum of Wales Geological Series No. 25, Cardiff.

Ridewood, W.G. 1920. A key for the ready identification of the species of Cephalodiscus. Annals and Magazine of Natural History, London 5 Series 9, 407-410.

DOI 10.1080/00222932008632393

Romer, A.S. 1967. Major steps in vertebrate evolution. Science 158, 1629-1637. DOI 10.1126/science.158.3809.1629

Ruedemann, R. 1908. Graptolites of New York. Part II: Graptolites of the Higher Beds. New York State Museum Memoir 11, 1-583.

Ruedemann, R. 1931. Some new Middle Cambrian Fossils from British Columbia. Proceedings of the United States National Museum 79(2893), 1-18.

DOI 10.5479/si.00963801.79-2893.1

Ruedemann, R. 1947. Graptolites of North America. Geological Society of America Memoir 19, 1-652.

DOI 10.1130/MEM19-p1

Simakov, O., Kawashima, T., Marlétaz, F., Jenkins, J., Koyanagi, R., Mitros, T., Hisata, K., Bredeson, J., Shoguchi, E., Gyoja, F., Yue, J.-X., Chen,Y.-C., Freeman, R., Sasaki, A., Hikosaka-Katayama, T., Sato, A., Fujie, M., Baughman, K., Levine, J., Gonzalez, P., Cameron, C., Fritzenwanker, J., Pani, A., Goto, H., Kanda, M., Arakaki, N., YamasaKi, S., Qu, J., Cree, A., Ding, Y., Dinh, H., Dugan, S., Holder, M., Jhangiani, S., Kovar, C., Lee, S., Lewis, L., Morton, D., Nazareth, L., Okwuonu, G., Santibanez, J., Chen, R., Richards, S., Muzny, D., Gillis, A., Peshrin, L., Wu, M.,
Humphreys, T., Su, Y.-H., Putnam, N., Schmutz, J., Fujiyama, A., Yu, Jr.-K., Tagawa, K., Worley, K., Gibbs, R., Kirschner, M., Lowe, C., Satoh, N., Rokhsar, D. \& Gerhart, J. 2015. Hemichordate genomes and deuterostome origins. Nature 527, 459-465. DOI 10.1038/nature16150

SKINNER, E.S. 2005. Taphonomy and depositional circumstances of exceptionally preserved fossils from the Kinzers Formation (Cambrian), Southeastern Pennsylvania. Palaeogeography, Palaeoclimatology, Palaeoecology 220, 167-192.

DOI 10.1016/j.palaeo.2004.09.015

Slater, B.J., Harvey, T.H.P. \& Butterfield, N.J. 2018a. Small carbonaceous fossils (SCFs) from the Terreneuvian (Lower Cambrian) of Baltica. Paleontology 61(3), 417-439.

DOI 10.1111/pala.12350

Slater, B.J., Willman, S., Budd, G.E. \& Peel, J.S. 2018b. Widespread preservation of small carbonaceous fossils (SCFs) in the early Cambrian of North Greenland. Geology 46(2), 107-110. DOI 10.1130/G39788.1

Steiner, M. \& Maletz, J. 2012. Cambrian graptolites (Pterobranchia) and the origin of colonial organization in metazoans. Centenary Meeting of the Paläontologische Gesellschaft. Programme, Abstracts and Field Guides, p. 174.

Swofford, D.L. 2002. PAUP: Phylogenetic Analysis Using Parsimony (and Other Methods), Version 4.0 Beta 10. Sinauer Associates, Sunderland.

Thomas, D.E. \& Henderson, Q.J. 1945. Some fossils from the Dundas Series, Dundas. Papers and Proceedings of the Royal Society of Tasmania 1944, 1-8.

Urbanek, A. 1983. The significance of graptoblasts in the life cycle of crustoid graptolites. Acta Palaeontologica Polonica 28(3-4), 313-326.

Urbanek, A. 1986. The enigma of graptolite ancestry: lesson from a phylogenetic debate, 184-226. In Hoffman, A. \& Nitecki, M. (eds) Problematic Fossil Taxa (Oxford Monographs on Geology and Geophysics $N^{\circ} 5$ ). Oxford University Press and Clarendon Press, Oxford.

Urbanek, A. \& Mierzejewski, P. 1984. The ultrastructure of the Crustoidea and the evolution of graptolite skeletal tissues. Lethaia 17, 73-91. DOI 10.1111/j.1502-3931.1984.tb00669.x

Urbanek, A. \& Towe, K.M. 1974. Ultrastructural studies on Graptolites 1. The Periderm and its derivatives in the Dendroidea and in Mastigograptus. Smithsonian contributions to Paleobiology 20, 1-49. DOI 10.5479/si.00810266.20.1

Walcott, C.D. 1879. The Utica Slate and related formations of the same geological horizon. Transactions of the Albany Institute 10, 1-17.

Walcott, C.D. 1919. Cambrian Geology and Paleontology IV. Middle Cambrian Algae. Smithsonian Miscellaneous Collections 67(2542), 217-260.

Zhao, F., Caron, J.B., Bottuer, D.J., Hu, S., Yin, Z. \& Zhu, M. 2013. Diversity and species abundance patterns of the early Cambrian (Series 2, Stage 3) Chengjiang Biota from China. Paleobiology 40, 50-69. DOI 10.1666/12056

Zhaо, Y., Zhu, M.Y., Baвсоск, L.E. \& Peng, J. 2011. The Kaili Biota: Marine Organisms from 508 Million Years Ago. 251 pp. Guizhou University Press, Guiyang. 